BNL-113260-2016-JA

\title{
Dynamic Oxygen on Surface: \\ Catalytic Intermediate and Coking Barrier in the Modeled CO2 Reforming of $\mathrm{CH} 4$ on Ni (111)
}

Kaidi Yuan, Jianqiang Zhong, Xiong Zhou, Leilei Xu, Susanna L. Bergman, Kai Wu, Guo Qin Xu, Steven L. Bernasek, Hexing Li and Wei Chen

Accepted in ACS Catalysis

June 2016

Center for Functional Nanomaterials

Brookhaven National Laboratory

U.S. Department of Energy

USDOE Office of Science, Basic Energy Sciences

Notice: This manuscript has been authored by employees of Brookhaven Science Associates, LLC under Contract No. DE-SC0012704 with the U.S. Department of Energy. The publisher by accepting the manuscript for publication acknowledges that the United States Government retains a non-exclusive, paid-up, irrevocable, world-wide license to publish or reproduce the published form of this manuscript, or allow others to do so, for United States Government purposes. 


\section{DISCLAIMER}

This report was prepared as an account of work sponsored by an agency of the United States Government. Neither the United States Government nor any agency thereof, nor any of their employees, nor any of their contractors, subcontractors, or their employees, makes any warranty, express or implied, or assumes any legal liability or responsibility for the accuracy, completeness, or any third party's use or the results of such use of any information, apparatus, product, or process disclosed, or represents that its use would not infringe privately owned rights. Reference herein to any specific commercial product, process, or service by trade name, trademark, manufacturer, or otherwise, does not necessarily constitute or imply its endorsement, recommendation, or favoring by the United States Government or any agency thereof or its contractors or subcontractors. The views and opinions of authors expressed herein do not necessarily state or reflect those of the United States Government or any agency thereof. 


\section{Dynamic Oxygen on Surface: Catalytic Intermediate and Coking Barrier in the Modeled $\mathrm{CO}_{2}$ Reforming of $\mathrm{CH}_{4}$ on $\mathrm{Ni}$ (111)}

Kaidi Yuan ${ }^{1,2}$, Jianqiang Zhong ${ }^{2,8}$, Xiong Zhou ${ }^{2,3}$, Leilei Xu' ${ }^{2}$, Susanna L. Bergman ${ }^{5,6}, \mathrm{Kai} \mathrm{Wu}^{2,4}$, Guo Qin $\mathrm{Xu}^{2,3}$, Steven L. Bernasek ${ }^{5,6}$, Hexing $\mathrm{Li}^{9}$, and Wei Chen ${ }^{1,2,3,7 *}$

1 Department of Physics, National University of Singapore, 2 Science Drive 3, 117542, Singapore

2 Singapore-Peking University Research Center for a Sustainable Low-Carbon Future, 1 CREATE Way, \#15-01, CREATE Tower, 138602, Singapore

3 Department of Chemistry, National University of Singapore, 3 Science Drive 3, 117543, Singapore

4 College of Chemistry and Molecular Engineering, Peking University, Beijing 100871, China

5 Science Division, Yale-NUS College, 16 College Avenue West, 138527, Singapore

6 Department of Chemistry, Princeton University, Princeton, New Jersey 08544, United States

7 National University of Singapore (Suzhou) Research Institute, 377 Linquan Street, Suzhou Industrial

Park, Jiangsu 215123, China

8 Center for Functional Nanomaterials, Brookhaven National Laboratory, Upton, New York 11973, United States

9 Chinese Education Ministry Key Laboratory of Resource Chemistry, Shanghai Normal University,

Shanghai 200234, China

*Corresponding Author Email Address: phycw@nus.edu.sg

\section{Abstract}

We identify $\mathrm{Ni}-\mathrm{O}$ phases as important intermediates in a model dry $\left(\mathrm{CO}_{2}\right)$ reforming of methane catalyzed by $\mathrm{Ni}(111)$, based on results from in operando near ambient X-ray photoelectron spectroscopy (NAP-XPS), low energy electron diffraction (LEED) and scanning tunneling microscopy (STM). We find that under a $\mathrm{CO}_{2}$ or $\mathrm{CO}_{2}-\mathrm{CH}_{4}$ atmosphere, the Ni-O phases exist as $\mathrm{p}(2 \times 2)$ structured chemisorbed oxygen (Chem-O), epitaxial $\mathrm{NiO}(111)$, or oxygen-rich $\mathrm{Ni}_{x} \mathrm{O}_{y}\left(x<y\right.$, typically $\left.\mathrm{Ni}_{2} \mathrm{O}_{3}\right)$, depending on the chemical potential. The growth rates of the $\mathrm{Ni}-\mathrm{O}$ phases have a negative correlation with temperature from $600 \mathrm{~K}$ to $900 \mathrm{~K}$, proving that their dynamic concentrations in the reaction are not limited by $\mathrm{CO}_{2}$ activation, but by their thermal stability. Between $300 \mathrm{~K}$ and $800 \mathrm{~K}\left(1: 1 \mathrm{CH}_{4}\right.$ and $\mathrm{CO}_{2}$ mixture), oxidation by $\mathrm{CO}_{2}$ is dominant, resulting in a fully $\mathrm{Ni}-\mathrm{O}$ covered surface. Between $800 \mathrm{~K}$ and $900 \mathrm{~K}$, a partially oxidized $\mathrm{Ni}(111)$ exists which could greatly facilitate the effective conversion of $\mathrm{CH}_{4} . \mathrm{As} \mathrm{CH}_{4}$ is activation-limited and dissociates mainly on metallic nickel, the released carbon species can quickly react with the adjacent oxygen (Ni-O phases) to form $\mathrm{CO}$. After combining with carbon and releasing $\mathrm{CO}$ molecules, the $\mathrm{Ni}-\mathrm{O}$ phases can be further regenerated through oxidation by $\mathrm{CO}_{2}$. In this way, the $\mathrm{Ni}-\mathrm{O}$ phases participate in the catalytic process, acting as an intermediate in addition to the previously reported $\mathrm{Ni}-\mathrm{C}$ phases. We also reveal the carbon phobic property of the $\mathrm{Ni}-\mathrm{O}$ phases, which links to the intrinsic coking resistance of the catalysts. The low dynamic coverage of 
surface oxygen at higher temperatures $(>900 \mathrm{~K})$ is inferred to be an underlying factor causing carbon aggregation. Therefore solutions based on $\mathrm{Ni}-\mathrm{O}$ stabilization are proposed in developing coking resisting catalysts.

\section{Introduction}

Carbon dioxide reforming of methane is a promising process for converting two major greenhouse gases to syngas (hydrogen and carbon monoxide) with a molar ratio of 1:1. Syngas can be further utilized as feedstock in the Fischer-Tropsch Reaction $\left(\mathrm{H}_{2}: \mathrm{CO}=2: 1\right)^{1,2}$ or methanol synthesis ${ }^{3,4}$ by mixing with the products from the steam reforming of methane $\left(\mathrm{H}_{2}: \mathrm{CO}=3: 1\right)$. Nickel has been reported as an efficient catalyst for this reaction and the rate-limiting step has been widely attributed to the activation of $\mathrm{CH}_{4}{ }^{5}$ due to its high activation energy revealed both by experimental and theoretical work: $0.52 \mathrm{eV}$ on $\mathrm{Ni}(100),{ }^{6,7} 0.74 \mathrm{eV}$ on $\mathrm{Ni}(111),{ }^{8}$ or $0.70 \sim 0.85 \mathrm{eV}$ on $\mathrm{Ni}(111){ }^{9}$ It has also been reported that the observed sticking probability of $\mathrm{CH}_{4}$ on nickel is as low as $10^{-9}$ at room temperature. ${ }^{10-12}$ Whereas in the reaction, there is still a surplus of carbon from pyrolysis of $\mathrm{CH}_{4}$ which aggregates into carbon filaments on the catalysts, causing deactivation through coking. ${ }^{13-15}$ This problem has been suggested to arise from the lack of accessible active oxygen species during the reaction. ${ }^{16}$

The oxygen shortage has previously been attributed to the $\mathrm{CO}_{2}$ activation step, ${ }^{17}$ and some argue that unlike the activation of $\mathrm{CH}_{4}$ which occurs on nickel, the $\mathrm{CO}_{2}$ can only be activated on acidic/basic supports, ${ }^{16,18,19}$ such as $\mathrm{Al}_{2} \mathrm{O}_{3}, \mathrm{MgO}, \mathrm{CaO}$ and $\mathrm{CeO}_{2} \cdot{ }^{2,19-22}$ The first statement has been debated since the calculated energy barrier for dissociative $\mathrm{CO}_{2}$ adsorption on nickel is $0.40 \mathrm{eV}$ lower than that of $\mathrm{CH}_{4}{ }^{23}$ The second one has similarly been challenged by experimental work. Ruckenstein et al investigated the NiO-MgO system using an isotopic pulse method, identifying the oxygen in nickel as an intermediate during the reaction. They distinguished "adsorbed oxygen" and "lattice oxygen" with different reactivity to carbon species through the gas responding curve. ${ }^{24}$ Another study by García-Diéguez et al determined that both $\mathrm{CH}_{4}$ and $\mathrm{CO}_{2}$ could be activated on the catalytic surface when separately introduced, and that the presence of $\mathrm{CH}_{\mathrm{x}}$ can promote $\mathrm{CO}_{2}$ activation. ${ }^{25}$ However, direct evidence of $\mathrm{CO}_{2}-\mathrm{Ni}$ interplay, especially in operando observations under reaction conditions, is still rare.

According to the Brønsted-Evans-Polany (BEP) relationship, ideal catalysts have low activation barriers for dissociative adsorption and moderate barriers for desorption. ${ }^{26}$ If the nickel oxides function as catalytic intermediates, they are likely to desorb from the substrate under conditions employed by traditional surface science approaches $\left(\sim 700^{\circ} \mathrm{C}\right.$ under ultrahigh vacuum, UHV). Therefore, most of these observations are limited to low substrate temperatures. ${ }^{27-29}$ The emergence of "near ambient pressure" (NAP) techniques have addressed some of these problems $^{30,31}$ as they operate at millibar pressures, at least 6 orders of magnitude higher than 
UHV conditions. For thermally metastable species, when the total effective collisions (proportional to pressure) exceed the desorbing molecules at elevated temperatures, the products on the surface become observable using methods such as X-ray photoelectron spectroscopy (XPS). The NAP techniques also make it possible to observe intermediates only coexisting with other pressure-sensitive species. ${ }^{32,33}$ In this way, direct observation of the competition and interaction between carbon species from $\mathrm{CH}_{4}$ and oxygen species from $\mathrm{CO}_{2}$ can be realized. In addition, NAP conditions can induce compositional redistribution in the solid phase, which can consequently affect the catalytic activity. ${ }^{32,33}$

Here we carry out studies employing near ambient pressure X-ray photoelectron spectroscopy (NAP-XPS), low energy electron diffraction (LEED) and scanning tunneling microscopy (STM) to understand the interactions of $\mathrm{CO}_{2}$ and $\mathrm{CO}_{2}-\mathrm{CH}_{4}$ mixtures with $\mathrm{Ni}(111)$ at elevated pressures (millibar) and temperatures $(300 \sim 900 \mathrm{~K})$. It is found that nickel exhibits bifunctional catalytic behavior in the $\mathrm{CO}_{2}-\mathrm{CH}_{4}$ system by dissociating both reactants in a similar manner as previously reported for the $\mathrm{Ru}-\mathrm{SiO}_{2}{ }^{19}$ and $\mathrm{Mo}_{2} \mathrm{C}-\mathrm{MoO}_{3}$ systems. ${ }^{34}$ We have observed the structural evolution of clean $\mathrm{Ni}(111)$ under millibar $\mathrm{CO}_{2}$ conditions, from chemisorbed $\mathrm{p}(2 \times 2)$ $\mathrm{O}$, epitaxial $\mathrm{NiO}(111)$, to an $\mathrm{O}$-rich $\mathrm{Ni}_{2} \mathrm{O}_{3}$ top layer. The interactions between $\mathrm{CO}_{2}$-derived $\mathrm{Ni}-\mathrm{O}$ phases and $\mathrm{CH}_{4}$ derived carbon species, as well as the regeneration of the $\mathrm{Ni}(111)$ have been clarified. Evidence of coking resistance originating from the $\mathrm{Ni}-\mathrm{O}$ phases is also presented.

\section{Experimental Section}

A clean $\mathrm{Ni}(111)$ surface was prepared through a series of sputtering-annealing cycles. Before each experiment, both the carbon and the oxygen levels were reduced below the detection limit of XPS, and a sharp $(1 \times 1)$ LEED pattern was obtained. At the beginning of each experiment (high pressure cell still under UHV conditions), the valence band (VB) and the $\mathrm{Ni} 2 p_{3 / 2}$ peak of the clean sample were measured to determine the Fermi Edge and the normalization factor respectively.

STM experiments were carried out in a multi-chamber Unisoku USM-1200 low temperature system with a base pressure below $1 \times 10^{-10} \mathrm{mbar}$. Before each characterization, the sample was cooled down to $77 \mathrm{~K}$ by liquid nitrogen and stabilized for a few hours. The electrochemically etched tungsten tip was grounded, and the voltage bias was applied to the sample.

NAP-XPS experiments were performed in a multi-chamber Specs system equipped with a $\mathrm{Mg}$-Al twin anode X-ray source, as well as a preparation chamber with LEED and residual gas analyzer (RGA) capabilities. The base pressure of the system was at $5 \times 10^{-10}$ mbar. A second RGA was installed in the NAP lens to probe the gas composition of the NAP cell through a 300 $\mu \mathrm{m}$ nozzle. Two independent gas lines provided gas flow to the NAP cell, effectively filling the NAP cell from UHV to millibar pressure within 1 2 minutes and therefore enabling time-resolved (TR) cascade measurements. In the TR working mode, samples were first heated to a pre-set 
temperature under UHV, and then dosed with reaction gas, instantly reaching the pre-set pressure. Repeated XPS measurements were carried out to record the dynamic evolution of the surface under non-equilibrium conditions. In the temperature programmed (TP) mode, the reaction gas was introduced at room temperature. The temperature was then increased in steps (typically consisting of 7 segments from $300 \mathrm{~K}$ to $900 \mathrm{~K}$ ) each with a "heating" and a "dwelling" period. NAP-XPS measurements were conducted at each temperature after sufficient dwelling time, in order to reach surface conditions close to equilibrium.

\section{Results and Discussion}

\subsection{Structural characterization of $\mathrm{CO}_{2}$-derived $\mathrm{Ni}-\mathrm{O}$ phases by STM and LEED: $p(2 \times 2)$ Chem-O and epitaxial NiO (111)}

The structures of $\mathrm{CO}_{2}$-derived Ni-O phases were characterized by STM and/or LEED after a separate treatment of $100 \mathrm{~L}$ (Langmuir) $\mathrm{CO}_{2}$ exposure at $1.3 \times 10^{-6} \mathrm{mbar}, 300 \mathrm{~K}$; and another series of consecutive treatments of (1) 0.4 mbar $\mathrm{CO}_{2}$ exposure at $600 \sim 700 \mathrm{~K}$ for 1 hour; (2) mild sputtering (500 V instead of regular $1500 \mathrm{~V}, 5 \mathrm{~min}$ ) and flashing in UHV at $773 \mathrm{~K}(1 \mathrm{~min})$ of the sample in (1); and (3) further annealing the sample in (2) in UHV at $973 \mathrm{~K}$. Similar to the $\mathrm{O}_{2}$ derived $\mathrm{Ni}-\mathrm{O}$ phases, ${ }^{35-37}$ both the $\mathrm{p}(2 \times 2)$ chemisorbed structure, and epitaxial $\mathrm{NiO}(111)$ were observed.

Figure 1 (a) shows an STM image after exposing the clean $\mathrm{Ni}(111)$ to $100 \mathrm{~L} \mathrm{CO}_{2}$ at room temperature. An ordered surface structure is observed with the unit cell marked by a white diamond $(0.51 \pm 0.03 \mathrm{~nm}$ in length). Considering the distance of $0.249 \mathrm{~nm}$ between adjacent atoms in $\mathrm{Ni}(111)$, this pattern is consistent with the $\mathrm{p}(2 \times 2)$ structure. For comparison, Figure 1 (b) shows the surface after $100 \mathrm{~L}$ dosing of $\mathrm{O}_{2}$ at $300 \mathrm{~K}$ and subsequent annealing in UHV at $773 \mathrm{~K}$. The unit cell also has the $p(2 \times 2)$ structure with a measured length of $0.49 \pm 0.04 \mathrm{~nm}$. In Figure 1

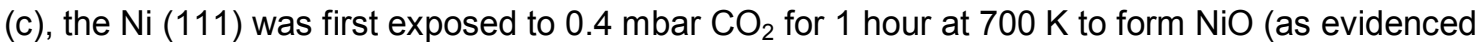
by LEED measurements), and then transferred to the STM chamber. To eliminate the effects of air contamination during the transfer, the sample was cleaned by mild sputtering ( $500 \mathrm{~V}, 5 \mathrm{~min}$ ) and UHV annealing (773 K, $1 \mathrm{~min})$ before imaging. The same $p(2 \times 2)$ pattern can be seen, and the defects (red dots) originating from thermal treatment are similarly distributed. Further heating the sample at elevated temperature $(973 \mathrm{~K})$ in UHV for 10 min resulted in near complete decomposition of the oxides, leaving a few oxide-phase islands, still maintaining the local $p(2 \times 2)-O$ structure on the bare $\mathrm{Ni}(111)$, as shown in Figure 1 (d). 

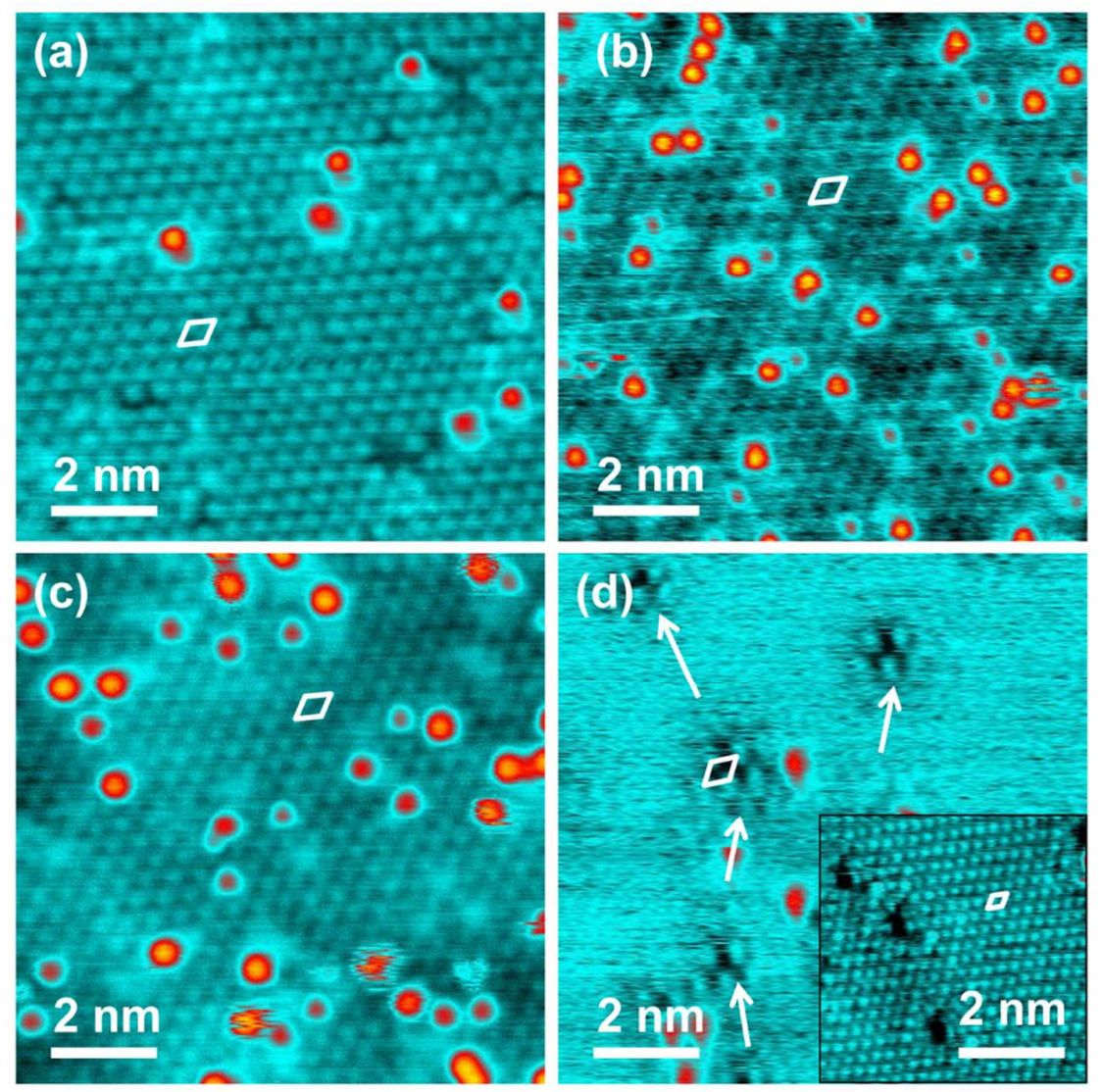

Figure 1. STM images of $\mathrm{Ni}-\mathrm{O}(2 \times 2)$ structures formed on $\mathrm{Ni}(111)$ after (a) exposing to $100 \mathrm{~L} \mathrm{CO}_{2}$ at room temperature; (b) after exposing to $100 \mathrm{~L} \mathrm{O}_{2}$ at RT followed by annealing at $773 \mathrm{~K}$; (c) after exposing to $0.4 \mathrm{mbar}$ $\mathrm{CO}_{2}$ for 1 hour at $700 \mathrm{~K}$, transferred in air, and cleaned by sputtering and annealing; and (d) after further annealing the sample corresponds to panel (c) at $973 \mathrm{~K}$, leaving residual Chem-O islands dispersed on the flat surface [insert illustrates the same surface showing the $\mathrm{Ni}$ (111) lattice]. The unit cells were marked by diamonds, and measured as (a) $0.51 \pm 0.03 \mathrm{~nm}$, (b) $0.49 \pm 0.04 \mathrm{~nm}$, (c) $0.48 \pm 0.03 \mathrm{~nm}$, (d) $0.49 \pm 0.04 \mathrm{~nm}$ for the residual islands, and $0.25 \pm 0.02 \mathrm{~nm}$ for the insert. The bias voltages and tunneling currents were (a) $-0.2 \mathrm{~V}, 0.1 \mathrm{nA}$; (b) $-0.05 \mathrm{~V}, 0.5 \mathrm{nA}$; (c) $-0.2 \mathrm{~V}, 0.1 \mathrm{nA}$; (d) $-0.1 \mathrm{~V}, 0.2 \mathrm{nA}$, and the insert $-0.1 \mathrm{~V}, 10 \mathrm{nA}$.

Figure 2 (a) shows the LEED pattern of clean $\mathrm{Ni}$ (111) using a beam energy of $70 \mathrm{eV}$. Sharp diffraction spots in six-fold symmetry can be seen. Figure 2 (b) shows the diffraction pattern of the $\mathrm{Ni}$ (111) sample after exposure to $0.4 \mathrm{mbar} \mathrm{CO}_{2}$ at $700 \mathrm{~K}$ for $30 \mathrm{~min}$. The beam energy and position were kept constant. Again the pattern shows the six-fold symmetry, epitaxial to that of $\mathrm{Ni}(111)$ as noted by the red dashed hexagon. By carefully measuring the diffraction lattices of the clean and the $\mathrm{CO}_{2}$-exposed samples, a ratio of 1.2 was obtained. This is consistent with the ratio between the sodium chloride structured $\mathrm{NiO}(111)(a=0.418 \mathrm{~nm})$ and the facecentered cubic $\mathrm{Ni}(111)(\mathrm{a}=0.3524 \mathrm{~nm})$. This ratio was also obtained when exposing the clean surface to $20 \sim 30 \mathrm{~L} \mathrm{O}_{2}$, see Figure $\mathrm{S} 1$, further proving the similarity between $\mathrm{CO}_{2}$-derived $\mathrm{NiO}$ and $\mathrm{O}_{2}$-derived $\mathrm{NiO}$. It is noted that the $\mathrm{NiO}(111)$ diffraction patterns of both origins are blurred. We attribute this to an amorphous $\mathrm{Ni}_{2} \mathrm{O}_{3}$ top layer as revealed by XPS in Figure 3 (a), and the small grain size of the formed oxides (less than $5 \mathrm{~nm}$ ) as similarly observed by Butcher et al in 
their $\mathrm{Pt}-\mathrm{O}_{2}$ system. ${ }^{38}$ Although the sodium chloride structured $\mathrm{NiO}$ is stable under an oxidizing atmosphere, its oxygen can be released from the surface if heated in UHV or reducing atmosphere. Figure $2(\mathrm{c}, \mathrm{d})$ show that after UHV annealing at $700 \mathrm{~K}$, the sodium chloride structured $\mathrm{NiO}(111)$ transformed into a $\mathrm{p}(2 \times 2)$ structure. Using a beam energy of $70 \mathrm{eV}$, another set of diffraction patterns with $30^{\circ}$ rotation could be identified (yellow hexagon). But this pattern became less significant when increasing the beam energy to $110 \mathrm{eV}$. As the beam of higher energy has larger penetration depth, it is inferred that the rotated pattern originates from decomposition of the topmost $\mathrm{Ni}_{2} \mathrm{O}_{3}$ layer. Compared with stoichiometric $\mathrm{NiO}$, the $\mathrm{p}(2 \times 2)$ Chem$\mathrm{O}$ structure has less dense oxygen concentration on the surface (4:1 nickel to oxygen atomic ratio) in a reducing environment, in agreement with the results by STM.
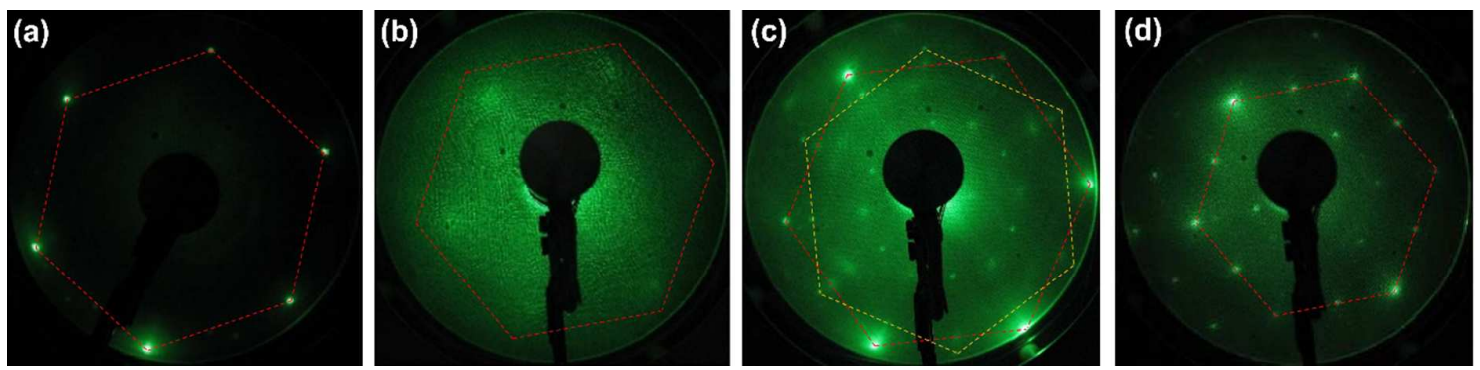

Figure 2. LEED patterns of (a) clean Ni (111), beam energy $70 \mathrm{eV}$; (b) after exposure to $0.4 \mathrm{mbar} \mathrm{CO}_{2}$ at $600 \mathrm{~K}$ for $30 \mathrm{~min}$, beam energy $70 \mathrm{eV}$, showing a shrinkage of the diffraction lattice consistent with epitaxial $\mathrm{NiO}(111)$ on $\mathrm{Ni}$ (111); and (c, d) the condition of (b) after UHV annealing, using $70 \mathrm{eV}$ and $110 \mathrm{eV}$ beams, showing the transition from $\mathrm{NiO}(111)$ to the $\mathrm{p}(2 \times 2)$ Chem-O structure. The hexagons in red dashed lines denote the unit diffraction lattice of clean $\mathrm{Ni}(111)$, and that in yellow dashed lines denotes a rotated pattern.

Both the STM and LEED results demonstrate that the $p(2 \times 2)$ structured Chem-O on $\mathrm{Ni}$ (111) can be obtained either after the initial exposure of a clean sample, or after moderate annealing of $\mathrm{NiO} / \mathrm{Ni}_{2} \mathrm{O}_{3}$ in $\mathrm{UHV}$. As $\mathrm{CO}_{2}$ is less reactive than $\mathrm{O}_{2}$ at room temperature, $100 \mathrm{~L} \mathrm{CO}$ dosing resulted in only partially covered Chem-O while less than $50 \mathrm{~L} \mathrm{O}_{2}$ dosage achieved full coverage $^{39-43}$ It was also observed that when the dosing was carried out at $973 \mathrm{~K}$ (at $1.3 \times 10^{-6}$ mbar), oxygen could rarely be found even after $1000 \mathrm{~L} \mathrm{CO}_{2}$ exposure, as shown in Figure $\mathrm{S} 2$. This illustrates the thermally unstable nature of the Chem-O phase. The dissociative adsorption of $\mathrm{CO}_{2}$ results in ${ }^{*} \mathrm{CO}$ and ${ }^{*} \mathrm{O}$ on the clean $\mathrm{Ni}$ surface, with $0.72 \mathrm{eV}$ energy released. ${ }^{44}$ Although the desorption of ${ }^{*} \mathrm{CO}$ is believed to be a strongly endothermic process on clean metal surfaces, ${ }^{19,59}$ in oxygen saturated nickel however, the desorption energy is reduced by about $0.17 \mathrm{eV}$ due to repulsive interactions between the surface oxygen and ${ }^{*} \mathrm{CO}$. As such, release of $\mathrm{CO}$ is possible at room temperature. ${ }^{45}$ This explains why the dominantly observed structure is the oxide phase rather than the ${ }^{*} \mathrm{CO}$ in Figure 1. 


\subsection{Temperature-programmed NAP-XPS characterization of $\mathrm{CO}_{2}-\mathrm{Ni}$ (111) interactions: identification of $\mathrm{NiO}$ and $\mathrm{Ni}_{2} \mathrm{O}_{3}$ phases}

The interaction between $\mathrm{CO}_{2}$ and $\mathrm{Ni}(111)$ was studied by temperature-programmed NAPXPS under $4.0 \times 10^{-1} \mathrm{mbar} \mathrm{CO}_{2}$ from $300 \mathrm{~K}$ to $900 \mathrm{~K}$. At each temperature, the system was allowed at least 2 hours to ensure equilibrium conditions. In Figure $3(\mathrm{a})$, three $\mathrm{O} 1 \mathrm{~s}$ peaks are clearly identified with binding energies of $536.8 \mathrm{eV}$ for gas phase $\mathrm{CO}_{2}, 531.5 \mathrm{eV}$ for $\mathrm{Ni}_{2} \mathrm{O}_{3}{ }^{46}$ and $529.5 \mathrm{eV}$ for $\mathrm{NiO}^{47,48}$ The latter two peaks are fitted by the red and green curves respectively, and their areas are illustrated in Figure $3(\mathrm{~d})$. The $\mathrm{Ni}_{2} \mathrm{O}_{3}$ content remains stable below $600 \mathrm{~K}$ but slowly decreases at higher temperatures, while the $\mathrm{NiO}$ keeps increasing until $900 \mathrm{~K}$. This is in agreement with previous reports showing that the $\mathrm{NiO}(111) / \mathrm{Ni}(111)$ interface is more stable. ${ }^{37,49,50}$ In Figure $3(\mathrm{~b})$, the $\mathrm{C} 1 \mathrm{~s}$ peak at $289.2 \mathrm{eV}$ is attributed to the adsorbed ${ }^{*} \mathrm{CO}_{2}{ }^{\delta-51}$ and that at around $293 \mathrm{eV}$ to gas phase $\mathrm{CO}_{2}$ affected by the surface work function. ${ }^{52-56}$ The peak area ratio of ${ }^{*} \mathrm{CO}_{2}{ }^{\delta-} / \mathrm{CO}_{2}$,gas is summarized in Figure $3(\mathrm{e})$. Similarly to the $\mathrm{O} 1 \mathrm{~s}$ case, there is also a gap present between $600 \mathrm{~K}$ and $700 \mathrm{~K}$. Figure 3 (c) shows the evolution of $\mathrm{Ni}_{2} \mathrm{p}_{3 / 2}$ peak. More metallic nickel was converted to nickel oxides with increasing temperature, as shown by the disappearance of the metallic peak at $852.4 \mathrm{eV}^{57}$ and the emerging of the $\mathrm{Ni}^{2+}$ peak at $854.4 \mathrm{eV}^{48}$ The $\mathrm{Ni}^{3+}$ peak ( $856.0 \mathrm{eV}$ ) was weak compared to the $\mathrm{Ni}^{0}$ and $\mathrm{Ni}^{2+}$, implying that the $\mathrm{Ni}_{2} \mathrm{O}_{3}$ existed as a single layered interface between the solid and gas phases. The relationship between the thickness of the $\mathrm{NiO}$ and the remaining $\mathrm{Ni}^{0}$ peak area (normalized by the area of clean nickel) was estimated using "oxides ( $\mathrm{NiO}, \mathrm{CuO}$, and $\mathrm{CoO}$ ) on Ni" models, and the SESSA 2.0 software. The result was plotted in Figure 3 (f). According to an exponential decay estimation, under a $1486.6 \mathrm{eV}$ incident beam, the inelastic mean free path (IMFP) for $\mathrm{Ni}^{0} 2 \mathrm{p}\left(\lambda_{\mathrm{Ni}}\right)$ is $1 \mathrm{~nm}$ (the Ni peak area decays by $1 / \mathrm{e}$ with $1.0 \mathrm{~nm} \mathrm{NiO}$ on top), and that for $\mathrm{O} 1 \mathrm{~s}\left(\lambda_{\circ}\right)$ is $2 \mathrm{~nm}$. 

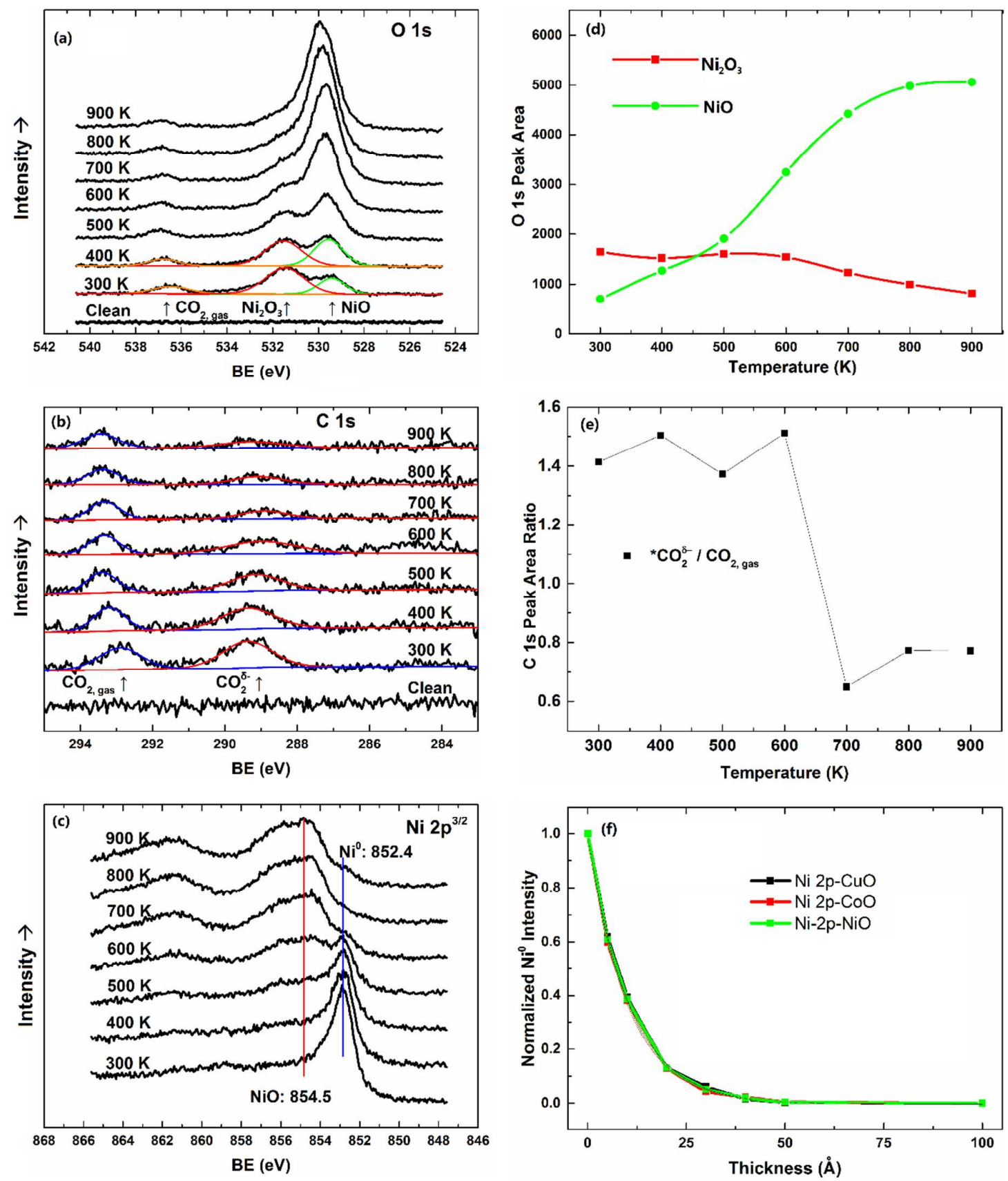

Figure 3. Temperature-programmed NAP-XPS under 0.4 mbar $\mathrm{CO}_{2}$ from $300 \mathrm{~K}$ to $900 \mathrm{~K}$. (a-c) $\mathrm{O} 1 \mathrm{~s}, \mathrm{C} 1 \mathrm{~s}$ and $\mathrm{Ni} 2 \mathrm{p}_{3 / 2}$ peaks. (d) Fitted $\mathrm{O} 1 \mathrm{~s}$ areas by $\mathrm{NiO}$ (green) and $\mathrm{Ni}_{2} \mathrm{O}_{3}$ (red). (e) C 1s area ratio of ${ }^{*} \mathrm{CO}_{2}{ }^{\delta-} / \mathrm{CO}_{2, \text { gas }}$. (f) SESSA 2.0 simulated $\mathrm{Ni}^{\circ} 2 \mathrm{p}$ intensity (normalized) from nickel substrates covered by $\mathrm{CuO}, \mathrm{CoO}$, and $\mathrm{NiO}$ with varying thicknesses.

Two activation mechanisms for $\mathrm{CO}_{2}$ on $\mathrm{Ni}(111)$ have been reported: dissociative adsorption (Eq. 1), ${ }^{18,58}$ and non-dissociative adsorption through charge transfer and molecular bending (Eq. 2.): ${ }^{38}$

$$
\begin{array}{ll}
\mathrm{CO}_{2} \rightarrow{ }^{*} \mathrm{CO}+{ }^{*} \mathrm{O} & (\text { Equation 1) } \\
\mathrm{CO}_{2}+\delta \mathrm{e}^{-} \rightarrow{ }^{*} \mathrm{CO}_{2}{ }^{\delta-} . & \text { (Equation 2) }
\end{array}
$$


In the dissociative mechanism, the dissociated products form Chem-O and ${ }^{*} \mathrm{CO}$ adsorbate with the $\mathrm{C}$ 1s peak located around $286 \mathrm{eV} .^{34,59}$ In the non-dissociative mechanism, partial electron transfers from $\mathrm{Ni}(111)$ to $\mathrm{CO}_{2}$ to form the negatively charged ${ }^{*} \mathrm{CO}_{2}{ }^{\delta-}$ adsorbate with the characteristic $\mathrm{C}$ 1s peak at $\sim 288.5 \mathrm{eV} .^{59,60}$ In Figure 3, although the existence of the Ni-O phase confirms the dissociation of $\mathrm{CO}_{2}$ at even room temperature, the dominant carbon adsorbate is the ${ }^{*} \mathrm{CO}_{2}{ }^{\delta-}$ rather than ${ }^{*} \mathrm{CO}$. This could be explained by the adsorption-desorption equilibrium. It is noted that the rate of dissociative adsorption is much lower than the collision of $\mathrm{CO}_{2}$ molecules $\left(>10^{5}\right.$ collisions per second at mbar pressure); whereas, the low * $\mathrm{CO}$ yielding rate cannot exceed the desorption of ${ }^{*} \mathrm{CO}$ in the circumstance of low $\mathrm{CO}$ base pressure $\left(<1 \times 10^{-9} \mathrm{mbar}\right)$ and weakened bond between ${ }^{*} \mathrm{CO}$ and $\mathrm{Ni}-\mathrm{O}$ phase $;{ }^{45}$ as a result, the major carbon species on the surface is ${ }^{*} \mathrm{CO}_{2}{ }^{\delta-}$. A similar effect was also reported in the case of a $\mathrm{CO} / \mathrm{H}_{2} \mathrm{O}$ mixture. ${ }^{59}$ Here, the adsorbate on $\mathrm{Cu}(111)$ was mainly in the form of ${ }^{*} \mathrm{CO}$, while on $\mathrm{CeO}_{\mathrm{x}} / \mathrm{Cu}(111)$ the ${ }^{*} \mathrm{CO}_{2}{ }^{\delta-}$ was found to dominate on the surface.

\subsection{Temperature-programmed NAP-XPS characterization under a $\mathrm{CH}_{4}$ and $\mathrm{CO}_{2}$ atmosphere: from fully carbon-covered $\mathrm{Ni}$, fully oxide- covered $\mathrm{Ni}$, to partially $(\mathrm{C}, \mathrm{O})$-covered $\mathrm{Ni}$}

To study the gas-nickel interface under conditions resembling the actual dry reforming reaction, a series of temperature-programmed NAP-XPS experiments were carried out in a gas mixture $\left(0.4\right.$ mbar $\mathrm{CH}_{4}$ and 0.4 mbar $\left.\mathrm{CO}_{2}\right)$ from $300 \mathrm{~K}$ to $900 \mathrm{~K}$. In Figure $4(\mathrm{a})$, the $\mathrm{O}$ 1s peaks belonging to gas phase $\mathrm{CO}_{2}$ locate near $537.0 \mathrm{eV}$. The peak positions have been affected by the change of the surface work function due to oxidation and reduction. The peaks at $531.5 \mathrm{eV}$ for $\mathrm{Ni}_{2} \mathrm{O}_{3}$ and $529.7 \mathrm{eV}$ for $\mathrm{NiO}$ are not observed at $300 \mathrm{~K}$. This is due to the passivation by carbon from pyrolysis of $\mathrm{CH}_{4}$ on $\mathrm{Ni}(111)$ and will be explained later. The Ni-O phase first appears at $400 \mathrm{~K}$, and increases until $700 \mathrm{~K}$. At $800 \mathrm{~K}$, the intensity decreases and the peak center shifts to higher binding energy by $\sim 0.3 \mathrm{eV}$ compared to the initial value. At $900 \mathrm{~K}$, neither of the two peaks ( $\mathrm{NiO}$ and $\mathrm{Ni}_{2} \mathrm{O}_{3}$ ) remains, as highlighted in green. In Figure 4 (b), the $\mathrm{C}$ 1s gas phase peaks for both $\mathrm{CO}_{2}$ and $\mathrm{CH}_{4}$ exhibit similar trends as the $\mathrm{O}$ 1s region: positive shifts between $400 \mathrm{~K}$ and $800 \mathrm{~K}$ and recovery at $900 \mathrm{~K}$. In the operation, $\mathrm{CH}_{4}$ was introduced before $\mathrm{CO}_{2}$ and the red spectrum for " $\mathrm{CH}_{4}$ only" has a characteristic peak at $283.7 \mathrm{eV}$. This peak can be attributed to the partially dissociated ${ }^{*} \mathrm{CH}$ with one remaining hydrogen ${ }^{27}$. It remains after the introduction of $\mathrm{CO}_{2}$ at $300 \mathrm{~K}$, but disappears at higher temperatures. In Figure 4 (c), the $\mathrm{Ni}^{0}$ peak turns weak between $400 \mathrm{~K}$ and $800 \mathrm{~K}$ due to surface oxidation, but recovers to the original intensity at $900 \mathrm{~K}$, indicating that the surface oxides have been completely reduced. 

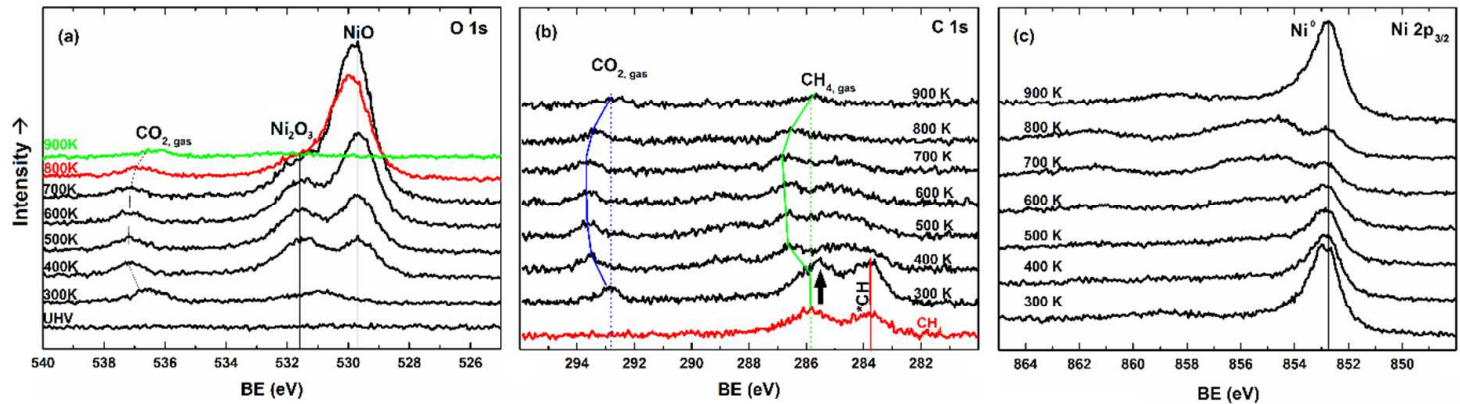

Figure 4. Temperature-programmed XP spectra of (a) $\mathrm{O} 1 \mathrm{~s}$, (b) $\mathrm{C}$ 1s and (c) $\mathrm{Ni} 2 \mathrm{p}_{3 / 2}$ under $0.4 \mathrm{mbar}^{\mathrm{C} \mathrm{CH}_{4}}$ and 0.4 mbar $\mathrm{CO}_{2}$.

Compared to the pure $\mathrm{CO}_{2}$ case (Figure 3), apart from the obvious difference in the high temperature $(800-900 \mathrm{~K})$ region, two additional features at $300 \mathrm{~K}$ can be observed under the mixed gas atmosphere. The first feature is due to the ${ }^{*} \mathrm{CH}$-induced surface passivation. Since $\mathrm{CH}_{4}$ was dosed first, the $\mathrm{Ni}$ (111) surface was covered by ${ }^{*} \mathrm{CH}$ species from $\mathrm{CH}_{4}$ pyrolysis. This carbon layer blocked the $\mathrm{Ni}-\mathrm{O}$ formation, as indicated by the absence of the characteristic $\mathrm{O} 1 \mathrm{~s}$ peak at $529.5 \mathrm{eV}$. Such passivation on nickel has been widely reported, with the carbon clusters varied from $\mathrm{CH}_{\mathrm{x}}$, graphite carbon to graphene. ${ }^{61-64}$ The second feature lies in the difference between $\mathrm{C}$ 1s spectra labeled " $\mathrm{CH}_{4}$ " (only $\mathrm{CH}_{4}$ at $300 \mathrm{~K}$ ) and " $300 \mathrm{~K}$ " $\left(\mathrm{CO}_{2}+\mathrm{CH}_{4}\right.$ at $300 \mathrm{~K}$ ). After introducing the $\mathrm{CO}_{2}$, although the ${ }^{*} \mathrm{CH}$ species were not removed, a new $\mathrm{C}$ 1s peak appeared at $285.7 \mathrm{eV}$ as pointed out by the arrow in Figure 4 (b), indicating the interaction between $\mathrm{CO}_{2}$-derived and $\mathrm{CH}_{4}$-derived intermediates. The peak is attributed to an oxidized form of the ${ }^{*} \mathrm{CH}$ species, which were completely consumed from $400 \mathrm{~K}$ onward, owing to the highly active $\mathrm{CO}_{2}$-nickel interface.

\subsection{Time-resolved NAP-XPS characterization of the Gas-Ni interface: revealing the metastable nature of the $\mathrm{Ni}-\mathrm{O}$ phases under $\mathrm{CO}_{2}$ and $\mathrm{CO}_{2} / \mathrm{CH}_{4}$ atmospheres}

In order to study the dynamic evolution of the $\mathrm{Ni}-\mathrm{O}$ phases affected by temperature and pressure, time-resolved (TR) NAP-XPS experiments were carried out by monitoring the $O 1 \mathrm{~s}$ peaks in intervals of several minutes. Normalized peak areas were plotted against time. Figure S3 demonstrates a continuous TR experiment with three independent variables: substrate temperature as well as the partial pressures of $\mathrm{CO}_{2}$ and $\mathrm{CH}_{4}$. Segments labelled from "A" to "R" represent specific combinations of parameters. For clarity, two typical data sets were selected and shown in the main text.

Figure 5 (a) shows the time-resolved oxidation of $\mathrm{Ni}(111)$ under pure $\mathrm{CO}_{2}$ from $600 \mathrm{~K}$ to $900 \mathrm{~K}$. It is discovered that the oxidation rate is temperature-sensitive with a strong negative correlation. At $900 \mathrm{~K}$, the oxygen level remains close to zero with respect to time. Upon slightly 
reducing the temperature to $880 \mathrm{~K}$, however, the increase of oxygen emerges. Further reducing the temperature from $850 \mathrm{~K}$ to $750 \mathrm{~K}$ results in an even higher growth rate. At temperatures between $750 \mathrm{~K}$ and $600 \mathrm{~K}$, the curves exhibit an almost instant step-up in the initial stage, followed by a near-saturation stage. Figure 5 (b) illustrates the reduction of the $\mathrm{Ni}-\mathrm{O}$ phase under $0.3 \mathrm{mbar} \mathrm{CH}_{4}$. The sample was from the $\mathrm{TR}-\mathrm{CO}_{2}$ treatment at $600 \mathrm{~K}$ in Figure 5 (a). During the initial 3 hours, the system was kept at $600 \mathrm{~K}$, but only a slight decrease in the oxygen was observed, showing that the $\mathrm{Ni}-\mathrm{O}$ phases remained stable at this temperature even in a reducing atmosphere. By increasing the temperature to $\sim 800 \mathrm{~K}$, the oxygen level quickly fell below the detection limit of XPS.
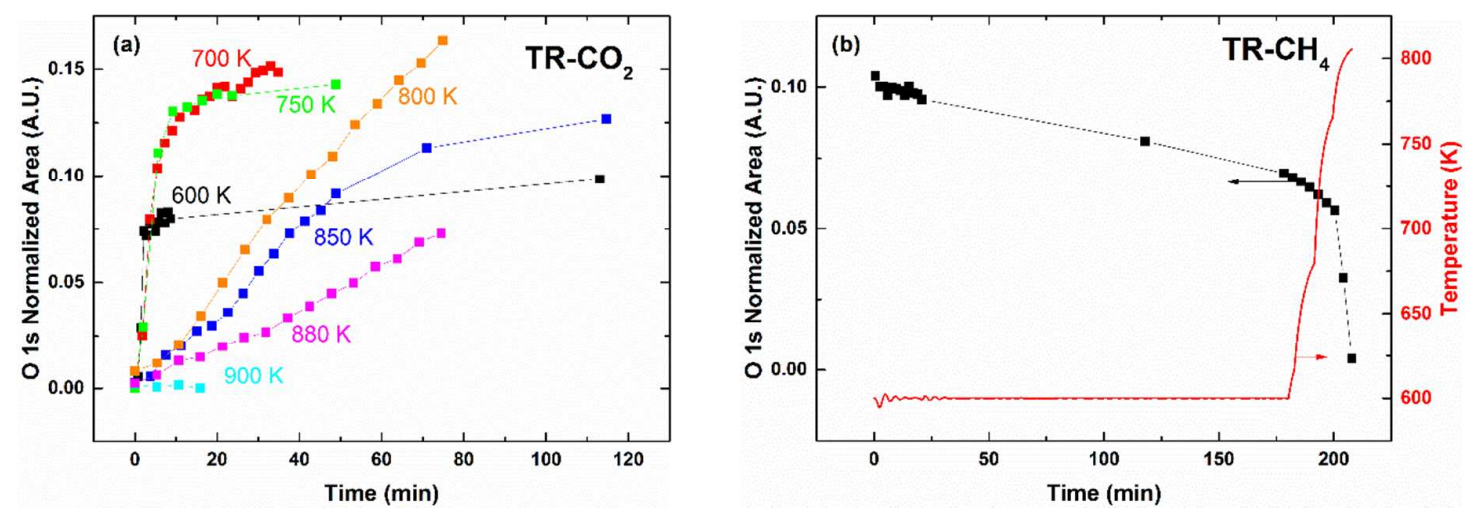

Figure 5. Time-resolved NAP-XPS showing the $\mathrm{O}$ 1s peak evolution. (a) Accumulation of oxygen under $0.4 \mathrm{mbar}$ $\mathrm{CO}_{2}$ at varying temperatures; (b) the reduction of the $\mathrm{Ni}-\mathrm{O}$ phase under $0.3 \mathrm{mbar} \mathrm{CH}_{4}$, prepared from the oxidation in (a) at $600 \mathrm{~K}$.

The combination of TP and TR measurements provides a deeper understanding of the model catalysis system. The "instant" step-up of oxygen in pure $\mathrm{CO}_{2}$ below $750 \mathrm{~K}$ [Figure 5 (a)], the prevailing oxidation in the $\mathrm{CO}_{2}-\mathrm{CH}_{4}$ mixture below $700 \mathrm{~K}$ (Figure 4), and the poor reducing ability of pure $\mathrm{CH}_{4}$ below $700 \mathrm{~K}$ [Figure 5 (b)] demonstrate that the activation of $\mathrm{CO}_{2}$ is not a limiting factor compared with $\mathrm{CH}_{4}$ activation. The energy barrier for $\mathrm{CO}_{2}$ dissociation to $\mathrm{CO}^{*}$ and $\mathrm{O}^{*}$ is not only lower than that of $\mathrm{CH}_{4}$ dissociation, but also the release/diffuse of $\mathrm{O}^{*}$ on the $\mathrm{Ni}$ surface. Unlike aluminum and magnesium that being oxidized in a nearly irreversible manner, the reversibility of the $\mathrm{Ni}-\mathrm{NiO}$ transition is a fundamental property of a catalyst operating in an atmosphere consisting of oxidizing and reducing gases. In vacuum decomposition has been reported by Maglia et al for single crystal $\mathrm{NiO}$ at temperatures around $773 \mathrm{~K},{ }^{65}$ and by Jang et al for thin film $\mathrm{NiO}$ at $673 \mathrm{~K}^{66}$ In the dry reforming reaction, high temperatures ( $\geq 800 \mathrm{~K}$ ) are mainly used to mobilize the $\mathrm{O}^{*}$, as well as to activate the dissociation of $\mathrm{CH}_{4}$ molecules. The released $\mathrm{O}^{*}$ from the $\mathrm{Ni}-\mathrm{O}$ reacts with carbon radicals from $\mathrm{CH}_{4}$, acting as a catalytic intermediate because the adsorbed thermal energy here is much lower than that required for directly breaking the $\mathrm{C}=\mathrm{O}$ bond in $\mathrm{CO}_{2}$. 


\subsection{Carbon-phobic properties of the $\mathrm{Ni}-\mathrm{O}$ phases and their role in coking resistance}

Coking is a major problem in catalysis caused by carbon aggregation on the surface. The carbon originates from either cracked $\mathrm{CH}_{4}$ species, ${ }^{62}$ or $\mathrm{CO}$ disproportionation through the Boudouard Reaction. ${ }^{16,66,67}$ As the chemical inertness of the carbon species is related to the bonding nature and size of the clusters, prevention of the spillover of carbon to form sp2 and sp3 networks is paramount. The intrinsic coking resistance of the partially oxidized nickel is based on three major mechanisms: the low $\mathrm{CH}_{4}$ cracking rate on $\mathrm{Ni}-\mathrm{O}$ phases controls carbon $\left(\mathrm{C}_{1}\right)$ supply, the released oxygen consumes the formed $\mathrm{C}_{1}$, and the surface oxygen blocks the diffusion of $\mathrm{C}_{1}$ and therefore reduces opportunity for $\mathrm{C}_{2}$ (and $\mathrm{C}_{n}$ ) formation. In macroscopy, such surface will behave as carbon phobic.

To compare the carbon philic/phobic properties of the $\mathrm{Ni}$ and $\mathrm{Ni}-\mathrm{O}$ phases, a pair of titration experiments were carried out at $700 \mathrm{~K}$ at which the activated $\mathrm{CH}_{4}$ is significant while the $\mathrm{NiO}$ could remain for hours. In Figure 6 (a), the clean $\mathrm{Ni}(111)$ was first dosed with 0.12 mbar $\mathrm{CH}_{4}$. In the $\mathrm{C}$ 1s spectrum, the gas phase peak and the peak for $\mathrm{Ni}_{x} \mathrm{C}(\mathrm{BE}=283.6 \mathrm{eV}$, attributed to a mixture of $\mathrm{Ni}_{2} \mathrm{C}$ and $\mathrm{Ni}_{3} \mathrm{C}^{68,69}$ ) can be clearly identified, showing carbon philic property of the metal surface. After finishing the XPS scan, the cell was filled by another 0.05 mbar $\mathrm{CO}_{2}$. Although the mixture was $\mathrm{CH}_{4}$ dominant $(70 \% \mathrm{v} / \mathrm{v})$, the $\mathrm{CH}_{4}$-derived $\mathrm{Ni}_{x} \mathrm{C}$ phase still disappeared. In a parallel experiment (Figure 6 (b)), the $\mathrm{Ni}(111)$ was first exposed to $0.4 \mathrm{mbar} \mathrm{CO}_{2}$ to form a $\mathrm{Ni}-\mathrm{O}$ layer on the surface. The cell was then evacuated to UHV to avoid possible Eley-Rideal type reaction between $\mathrm{CO}_{2}$ and $\mathrm{Ni}_{x} \mathrm{C}$. Subsequently, pure $\mathrm{CH}_{4}$ at 0.12 mbar was introduced to the cell. In contrast to the metallic surface, carbon adsorbates can rarely be found in the spectrum (except for the gas phase peak of $\mathrm{CH}_{4}$ which disappeared after $\mathrm{CH}_{4}$ evacuation), indicating that the oxygen covered surface is carbon phobic.
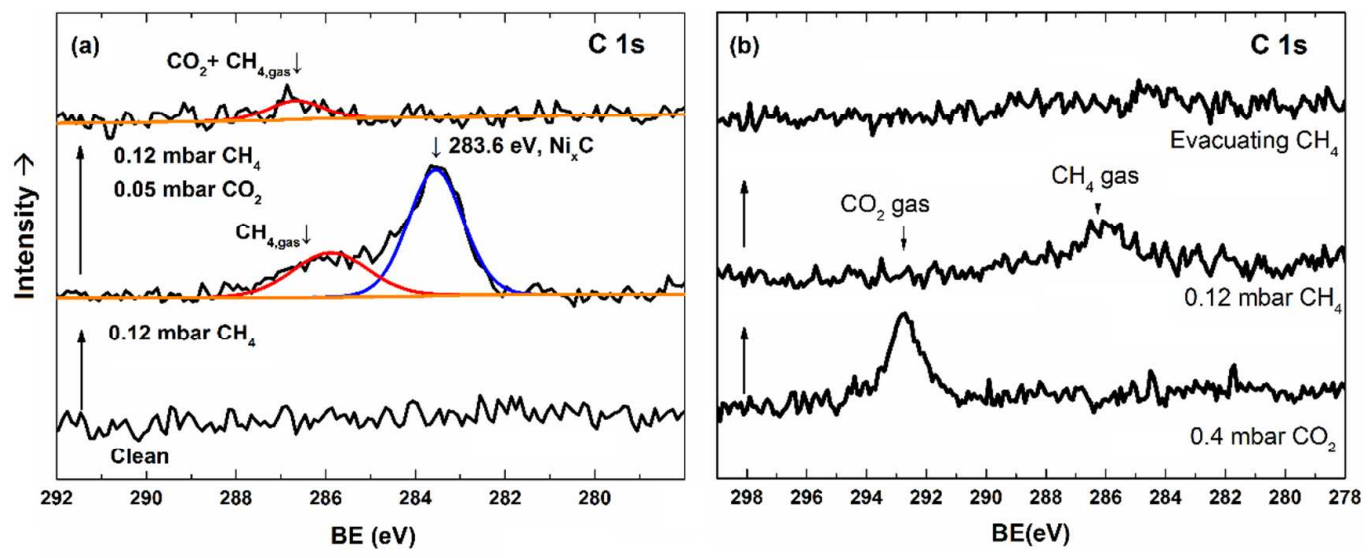

Figure 6. Titration experiments at $700 \mathrm{~K}$ with varying gas dosing sequences. In (a), the $\mathrm{Ni}(111)$ was first exposed to 0.12 mbar $\mathrm{CH}_{4}$ at $700 \mathrm{~K}$ and $\mathrm{Ni}_{x} \mathrm{C}$ clusters were formed; after adding another 0.05 mbar $\mathrm{CO}_{2}$, the $\mathrm{Ni}_{x} \mathrm{C}$ phase 
disappeared. In (b), the $\mathrm{Ni}(111)$ was first exposed to $0.4 \mathrm{mbar} \mathrm{CO}_{2}$ at $700 \mathrm{~K}$ to form a $\mathrm{NiO}$ surface; after evacuating the $\mathrm{CO}_{2}$ and adding $0.12 \mathrm{mbar}^{\mathrm{CH}} \mathrm{H}_{4}$, no carbon deposition was observed on the oxidized surface except for the gas phase $\mathrm{CH}_{4}$ peak, which disappeared after evacuating $\mathrm{CH}_{4}$.

Due to the metastable and carbon phobic nature of the Ni-O phase, by tuning its dynamic concentration using temperature and partial pressure, the amount of surface carbon is able to be controlled. Ideally, a Ni surface partially covered by surface oxides could maximize the relative collision rate of $\mathrm{CH}_{4},{ }^{5,70}$ and partition catalysts into smaller ensembles similar to bi-metallic alloying and potassium doping ${ }^{71}$ which show higher resistance to coking. In this way, a correlation between surface oxygen and coking resistance can be established. A similar link can also be found in some noble metals like $\mathrm{Ru}^{72,73} \mathrm{Pd}^{70,74} \mathrm{Ir}^{75}$ and $\mathrm{Pt}^{38,76}$ that show high coking resistance in the dry reforming reaction ${ }^{5,18,41,16,77}$ However, the authors had not yet related the coking performance to the known surface oxides of these metals in the reaction ambient.

At current dry reforming temperatures $(1000 \sim 1274 \mathrm{~K}),{ }^{18}$ the role of intrinsic coking resistance from the $\mathrm{Ni}-\mathrm{O}$ phase on single crystal $\mathrm{Ni}(111)$ is suppressed. On one hand, the lifetime of the surface oxygen decreases; on the other hand, a larger portion of $\mathrm{CH}_{4}$ molecules are thermally dissociated; both contributing to the spillover of carbon species. Therefore the stabilization of the $\mathrm{Ni}-\mathrm{O}$ phase under operating temperatures becomes an open question. One possible method is to reduce the catalyst into nanoparticles and confine them to mesoporous structures, as the oxides become more stable due to the size effect. ${ }^{78,79}$ In addition, diffusion of oxygen through the bulk is more significant on the nano-scale, enhancing another oxygen supply channel, i.e. the migration from support to surface. Therefore the oxygen activated in the support can also make a positive contribution to the metal surface.

\section{Conclusion}

Dissociation of $\mathrm{CO}_{2}$ on the $\mathrm{Ni}(111)$ surface at temperatures between 300 and $900 \mathrm{~K}$ has been observed in operando by NAP-XPS. $\mathrm{CO}_{2}$ quickly reacts with clean nickel and forms various $\mathrm{Ni}-\mathrm{O}$ phases even at room temperature: initially the $\mathrm{p}(2 \times 2)$ structured Chem-O, followed by epitaxial $\mathrm{NiO}$ (111) with a sodium chloride structure and finally an oxygen enriched surface layer of $\mathrm{Ni}_{2} \mathrm{O}_{3}$ under oxidative potential. For the $\mathrm{Ni}-\mathrm{O}$ phases, we discover that their accumulation rate under $\mathrm{CO}_{2}$ has a negative correlation with temperature, revealing that the dynamic oxygen concentration is not limited by $\mathrm{CO}_{2}$ activation, but the thermal decomposition of the $\mathrm{Ni}-\mathrm{O}$ phases. The $\mathrm{Ni}-\mathrm{O}$ phases exhibit carbon phobic properties due to repulsive force to ${ }^{*} \mathrm{CO}$ adsorbate and lower $\mathrm{C}-\mathrm{H}$ bond scission rate than metallic $\mathrm{Ni}$, showing intrinsic coking resistance. The releasing of oxygen from both $\mathrm{NiO}$ and $\mathrm{Chem}-\mathrm{O}$ is verified upon heating, acting as an intermediate to react with the carbon species from dissociated $\mathrm{CH}_{4}$. Therefore it is inferred that maintaining a certain level of surface oxygen can optimize the utilization of $\mathrm{CH}_{4}$ and improve the coking resistance. There are already reports on the catalytic improvement from partially oxidized transition metals 
$\left(\mathrm{Fe},{ }^{80} \mathrm{Co},{ }^{81} \mathrm{Ni},{ }^{82} \mathrm{Pd},{ }^{83,84}\right.$ and $\left.\mathrm{Pt}^{76}\right)$, with oxygen originating from either atmosphere or reactive supports. From the perspective of surface oxygen, it is interestingly found that many of current coking prevention methods such as size reduction, ${ }^{5}$ alkaline ion doping, ${ }^{71}$ use of reducing supports $\left(\mathrm{CeO}_{\mathrm{x}} \text { and } \mathrm{TiO}_{\mathrm{x}}\right)^{60}$ and noble metals alloying, are increasing the surface oxygen concentration of the active metal in essence. 


\section{Acknowledgements}

The authors acknowledge the financial support from Singapore MOE grant R143-000-542-112, Singapore National Research Foundation CREATE-SPURc program R-143-001-205-592, NFSC program (21573156), and Academia-Industry Collaborative Innovation Foundation 20121G00421 and BY2014139 from Jiangsu Science and Technology Department.

\section{References}

(1) Dry, M. E. Catalysis Today 2002, 71, 227.

(2) Olah, G. A.; Goeppert, A.; Czaun, M.; Prakash, G. K. S. Journal of the American Chemical Society 2012, 135, 648.

(3) Olah, G. A.; Goeppert, A.; Czaun, M.; Mathew, T.; May, R. B.; Prakash, G. K. S. Journal of the American Chemical Society 2015, 137, 8720.

(4) Goeppert, A.; Czaun, M.; Jones, J.-P.; Surya Prakash, G. K.; Olah, G. A. Chemical Society Reviews 2014, 43, 7995.

(5) Chin, Y.-H.; Buda, C.; Neurock, M.; Iglesia, E. Journal of the American Chemical Society 2011, 133, 15958.

(6) Chorkendorff, I.; Alstrup, I.; Ullmann, S. Surface Science 1990, 227, 291.

(7) Holmblad, P. M.; Wambach, J.; Chorkendorff, I. The Journal of Chemical Physics 1995, 102,8255 .

(8) Yang, H.; Whitten, J. L. The Journal of Chemical Physics 1992, 96, 5529.

(9) Watwe, R. M.; Bengaard, H. S.; Rostrup-Nielsen, J. R.; Dumesic, J. A.; Nørskov, J. K. Journal of Catalysis 2000, 189, 16.

(10) Bengaard, H. S.; Alstrup, I.; Chorkendorff, I.; Ullmann, S.; Rostrup-Nielsen, J. R.; Nørskov, J. K. Journal of Catalysis 1999, 187, 238.

(11) Abild-Pedersen, F.; Lytken, O.; Engbæk, J.; Nielsen, G.; Chorkendorff, I.; Nørskov, J. K. Surface Science 2005, 590, 127.

(12) Schouten, F. C.; Gijzeman, O. L. J.; Bootsma, G. A. Surface Science 1979, 87, 1.

(13) Snoeck, J. W.; Froment, G. F.; Fowles, M. Journal of Catalysis 1997, 169, 250.

(14) Li, K.; Jiao, M.; Wang, Y.; Wu, Z. Surface Science 2013, 617, 149.

(15) Xu, L.; Song, H.; Chou, L. Catalysis Science \& Technology 2011, 1, 1032.

(16) Pakhare, D.; Spivey, J. Chemical Society Reviews 2014, 43, 7813.

(17) Kawi, S.; Kathiraser, Y.; Ni, J.; Oemar, U.; Li, Z.; Saw, E. T. ChemSusChem 2015, 8,

3556.

(18) Nagaoka, K.; Seshan, K.; Lercher, J.; Aika, K.-i. Catalysis Letters 2000, 70, 109.

(19) Ferreira-Aparicio, P.; Rodríguez-Ramos, I.; Anderson, J. A.; Guerrero-Ruiz, A. Applied Catalysis A: General 2000, 202, 183.

(20) Xu, L.; Song, H.; Chou, L. ACS Catalysis 2012, 2, 1331.

(21) Xu, L.; Song, H.; Chou, L. Applied Catalysis B: Environmental 2011, 108-109, 177.

(22) Xu, M.; Iglesia, E. The Journal of Physical Chemistry B 1998, 102, 961.

(23) Wang, S.-G.; Cao, D.-B.; Li, Y.-W.; Wang, J.; Jiao, H. The Journal of Physical Chemistry B 2006, 110, 9976.

(24) Ruckenstein, E.; Hu, Y. Catalysis Letters 1998, 51, 183.

(25) García-Diéguez, M.; Pieta, I. S.; Herrera, M. C.; Larrubia, M. A.; Malpartida, I.; Alemany, L. J. Catalysis Today 2010, 149, 380.

(26) Norskov, J. K.; Bligaard, T.; Hvolbaek, B.; Abild-Pedersen, F.; Chorkendorff, I.; Christensen, C. H. Chemical Society Reviews 2008, 37, 2163.

(27) Larciprete, R.; Goldoni, A.; Groŝo, A.; Lizzit, S.; Paolucci, G. Surface Science 2001, 482-485, Part 1, 134. 
(28) Vesselli, E.; Rogatis, L. D.; Ding, X.; Baraldi, A.; Savio, L.; Vattuone, L.; Rocca, M.; Fornasiero, P.; Peressi, M.; Baldereschi, A.; Rosei, R.; Comelli, G. Journal of the American Chemical Society 2008, 130, 11417.

(29) Feng, X.; Cerdá, J. I.; Salmeron, M. The Journal of Physical Chemistry Letters 2015, 6, 1780.

(30) Frank Ogletree, D.; Bluhm, H.; Hebenstreit, E. D.; Salmeron, M. Nuclear Instruments and Methods in Physics Research Section A: Accelerators, Spectrometers, Detectors and Associated Equipment 2009, 601, 151.

(31) Tao, F.; Grass, M. E.; Zhang, Y.; Butcher, D. R.; Renzas, J. R.; Liu, Z.; Chung, J. Y.; Mun, B. S.; Salmeron, M.; Somorjai, G. A. Science 2008, 322, 932.

(32) Hansen, P. L.; Wagner, J. B.; Helveg, S.; Rostrup-Nielsen, J. R.; Clausen, B. S.; Topsøe, H. Science 2002, 295, 2053.

(33) Tan, K.; Zuluaga, S.; Gong, Q.; Gao, Y.; Nijem, N.; Li, J.; Thonhauser, T.; Chabal, Y. J. Chemistry of Materials 2015, 27, 2203.

(34) Porosoff, M. D.; Yang, X.; Boscoboinik, J. A.; Chen, J. G. Angewandte Chemie International Edition 2014, 53, 6705.

(35) Narusawa, T.; Gibson, W. M.; Törnqvist, E. Surface Science 1982, 114, 331.

(36) Tyuliev, G. T.; Kostov, K. L. Physical Review B 1999, 60, 2900.

(37) Hildebrandt, S.; Hagendorf, C.; Doege, T.; Jeckstiess, C.; Kulla, R.; Neddermeyer, H.; Uttich, T. Journal of Vacuum Science \&amp; Technology A 2000, 18, 1010.

(38) Butcher, D. R.; Grass, M. E.; Zeng, Z.; Aksoy, F.; Bluhm, H.; Li, W.-X.; Mun, B. S.; Somorjai, G. A.; Liu, Z. Journal of the American Chemical Society 2011, 133, 20319.

(39) Saiki, R.; Kaduwela, A.; Osterwalder, J.; Sagurton, M.; Fadley, C. S.; Brundle, C. R. Journal of Vacuum Science \&amp; Technology A 1987, 5, 932.

(40) Hall, R. B.; Chen, J. G.; Hardenbergh, J. H.; Mims, C. A. Langmuir 1991, 7, 2548.

(41) Kuhlenbeck, H.; Odörfer, G.; Jaeger, R.; Illing, G.; Menges, M.; Mull, T.; Freund, H. J.; Pöhlchen, M.; Staemmler, V.; Witzel, S.; Scharfschwerdt, C.; Wennemann, K.; Liedtke, T.; Neumann, M. Physical Review B 1991, 43, 1969.

(42) Stöhr, J.; Jaeger, R.; Kendelewicz, T. Phys. Rev. Lett. 1982, 49, 142.

(43) Pedio, M.; Becker, L.; Hillert, B.; D’Addato, S.; Haase, J. Physical Review B 1990, 41, 7462.

(44) Wang, S.-G.; Cao, D.-B.; Li, Y.-W.; Wang, J.; Jiao, H. The Journal of Physical Chemistry B 2005, 109, 18956.

(45) Conrad, H.; Ertl, G.; Küppers, J.; Latta, E. E. Surface Science 1976, 57, 475.

(46) Fleisch, T.; Winograd, N.; Delgass, W. N. Surface Science 1978, 78, 141.

(47) Oku, M.; Tokuda, H.; Hirokawa, K. Journal of Electron Spectroscopy and Related Phenomena 1991, 53, 201.

(48) Mansour, A. N. Surface Science Spectra 1994, 3, 231.

(49) Kitakatsu, N.; Maurice, V.; Marcus, P. Surface Science 1998, 411, 215.

(50) Holloway, P. H.; Hudson, J. B. Journal of Vacuum Science \&amp; Technology 1975, 12,

647.

(51) Eren, B.; Heine, C.; Bluhm, H.; Somorjai, G. A.; Salmeron, M. Journal of the American Chemical Society 2015, 137, 11186.

(52) Pantförder, J.; Pöllmann, S.; Zhu, J. F.; Borgmann, D.; Denecke, R.; Steinrück, H.-P. Review of Scientific Instruments 2005, 76, 014102.

(53) Óvári, L.; Krick Calderon, S.; Lykhach, Y.; Libuda, J.; Erdőhelyi, A.; Papp, C.; Kiss, J.; Steinrück, H. P. Journal of Catalysis 2013, 307, 132.

(54) Eichelbaum, M.; Hävecker, M.; Heine, C.; Wernbacher, A. M.; Rosowski, F.; Trunschke, A.; Schlögl, R. Angewandte Chemie International Edition 2015, 54, 2922.

(55) Jugnet, Y.; Loffreda, D.; Dupont, C.; Delbecq, F.; Ehret, E.; Cadete Santos Aires, F. J.; Mun, B. S.; Aksoy Akgul, F.; Liu, Z. The Journal of Physical Chemistry Letters 2012, 3, 3707. 
(56) Axnanda, S.; Scheele, M.; Crumlin, E.; Mao, B.; Chang, R.; Rani, S.; Faiz, M.; Wang, S.; Alivisatos, A. P.; Liu, Z. Nano Letters 2013, 13, 6176.

(57) Roustila, A.; Severac, C.; Chêne, J.; Percheron-Guégan, A. Surface Science 1994, 311, 33.

(58) Nakamura, J.; Rodriguez, J. A.; Campbell, C. T. Journal of Physics: Condensed Matter 1989, 1, SB149.

(59) Mudiyanselage, K.; Senanayake, S. D.; Feria, L.; Kundu, S.; Baber, A. E.; Graciani, J.; Vidal, A. B.; Agnoli, S.; Evans, J.; Chang, R.; Axnanda, S.; Liu, Z.; Sanz, J. F.; Liu, P.; Rodriguez, J. A.; Stacchiola, D. J. Angewandte Chemie International Edition 2013, 52, 5101.

(60) Graciani, J.; Mudiyanselage, K.; Xu, F.; Baber, A. E.; Evans, J.; Senanayake, S. D.; Stacchiola, D. J.; Liu, P.; Hrbek, J.; Sanz, J. F.; Rodriguez, J. A. Science 2014, 345, 546.

(61) Urasaki, K.; Sekine, Y.; Kawabe, S.; Kikuchi, E.; Matsukata, M. Applied Catalysis A: General 2005, 286, 23.

(62) Weatherup, R. S.; D’Arsié, L.; Cabrero-Vilatela, A.; Caneva, S.; Blume, R.; Robertson, J.; Schloegl, R.; Hofmann, S. Journal of the American Chemical Society 2015.

(63) Rostrup-Nielsen, J. R. Journal of Catalysis 1974, 33, 184.

(64) Monachino, E.; Greiner, M.; Knop-Gericke, A.; Schlögl, R.; Dri, C.; Vesselli, E.; Comelli, G. The Journal of Physical Chemistry Letters 2014, 5, 1929.

(65) Maglia, F.; Spinolo, G.; Anselmi-Tamburini, U. Solid State Sciences 2009, 11, 1686.

(66) Jang, W. L.; Lu, Y. M.; Hwang, W. S.; Dong, C. L.; Hsieh, P. H.; Chen, C. L.; Chan, T. S.; Lee, J. F. EPL (Europhysics Letters) 2011, 96, 37009.

(67) Ginsburg, J. M.; Piña, J.; El Solh, T.; de Lasa, H. I. Industrial \& Engineering Chemistry Research 2005, 44, 4846.

(68) Sinharoy, S.; Levenson, L. L. Thin Solid Films 1978, 53, 31.

(69) Jacobson, P.; Stöger, B.; Garhofer, A.; Parkinson, G. S.; Schmid, M.; Caudillo, R.; Mittendorfer, F.; Redinger, J.; Diebold, U. ACS Nano 2012, 6, 3564.

(70) Chin, Y.-H.; Buda, C.; Neurock, M.; Iglesia, E. Journal of the American Chemical Society 2013.

(71) Chen, C. S.; Lin, J. H.; You, J. H.; Yang, K. H. The Journal of Physical Chemistry A 2010, $114,3773$.

(72) Zhu, Z.; Butcher, D. R.; Mao, B.; Liu, Z.; Salmeron, M.; Somorjai, G. A. In ABSTRACTS OF PAPERS OF THE AMERICAN CHEMICAL SOCIETY; AMER CHEMICAL SOC 1155 16TH ST, NW, WASHINGTON, DC 20036 USA: 2013; Vol. 245.

(73) Over, H.; Kim, Y. D.; Seitsonen, A. P.; Wendt, S.; Lundgren, E.; Schmid, M.; Varga, P.; Morgante, A.; Ertl, G. Science 2000, 287, 1474.

(74) Chin, Y.-H.; Iglesia, E. The Journal of Physical Chemistry C 2011, 115, 17845.

(75) Sanchez Casalongue, H. G.; Ng, M. L.; Kaya, S.; Friebel, D.; Ogasawara, H.; Nilsson, A. Angewandte Chemie International Edition 2014, 53, 7169.

(76) Zhu, Z.; Melaet, G.; Axnanda, S.; Alayoglu, S.; Liu, Z.; Salmeron, M.; Somorjai, G. A. Journal of the American Chemical Society 2013, 135, 12560.

(77) Mark, M. F.; Maier, W. F. Angewandte Chemie International Edition in English 1994, 33, 1657.

(78) Grass, M. E.; Zhang, Y.; Butcher, D. R.; Park, J. Y.; Li, Y.; Bluhm, H.; Bratlie, K. M.; Zhang, T.; Somorjai, G. A. Angewandte Chemie International Edition 2008, 47, 8893.

(79) Navrotsky, A.; Ma, C.; Lilova, K.; Birkner, N. Science 2010, 330, 199.

(80) Merte, L. R.; Knudsen, J.; Eichhorn, F. M.; Porsgaard, S.; Zeuthen, H.; Grabow, L. C.; Lægsgaard, E.; Bluhm, H.; Salmeron, M.; Mavrikakis, M.; Besenbacher, F. Journal of the American Chemical Society 2011, 133, 10692.

(81) Melaet, G.; Ralston, W. T.; Li, C.-S.; Alayoglu, S.; An, K.; Musselwhite, N.; Kalkan, B.; Somorjai, G. A. Journal of the American Chemical Society 2014, 136, 2260. 
(82) Mu, R.; Fu, Q.; Xu, H.; Zhang, H.; Huang, Y.; Jiang, Z.; Zhang, S.; Tan, D.; Bao, X. Journal of the American Chemical Society 2011, 133, 1978.

(83) Teschner, D.; Pestryakov, A.; Kleimenov, E.; Hävecker, M.; Bluhm, H.; Sauer, H.; Knop-Gericke, A.; Schlögl, R. Journal of Catalysis 2005, 230, 186.

(84) Gabasch, H.; Hayek, K.; Klötzer, B.; Unterberger, W.; Kleimenov, E.; Teschner, D.; Zafeiratos, S.; Hävecker, M.; Knop-Gericke, A.; Schlögl, R.; Aszalos-Kiss, B.; Zemlyanov, D. The Journal of Physical Chemistry C 2007, 111, 7957. 
Page 19 of 26

\section{Table of Contents Graphic}

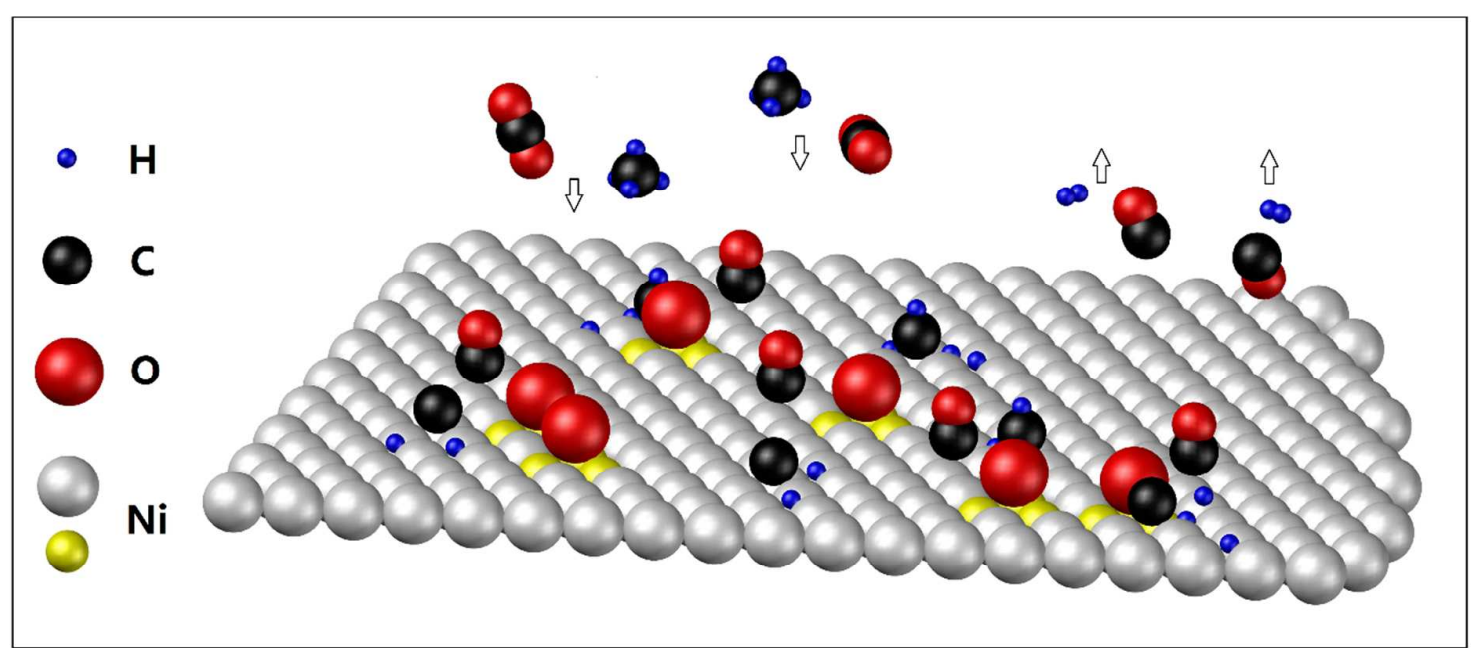



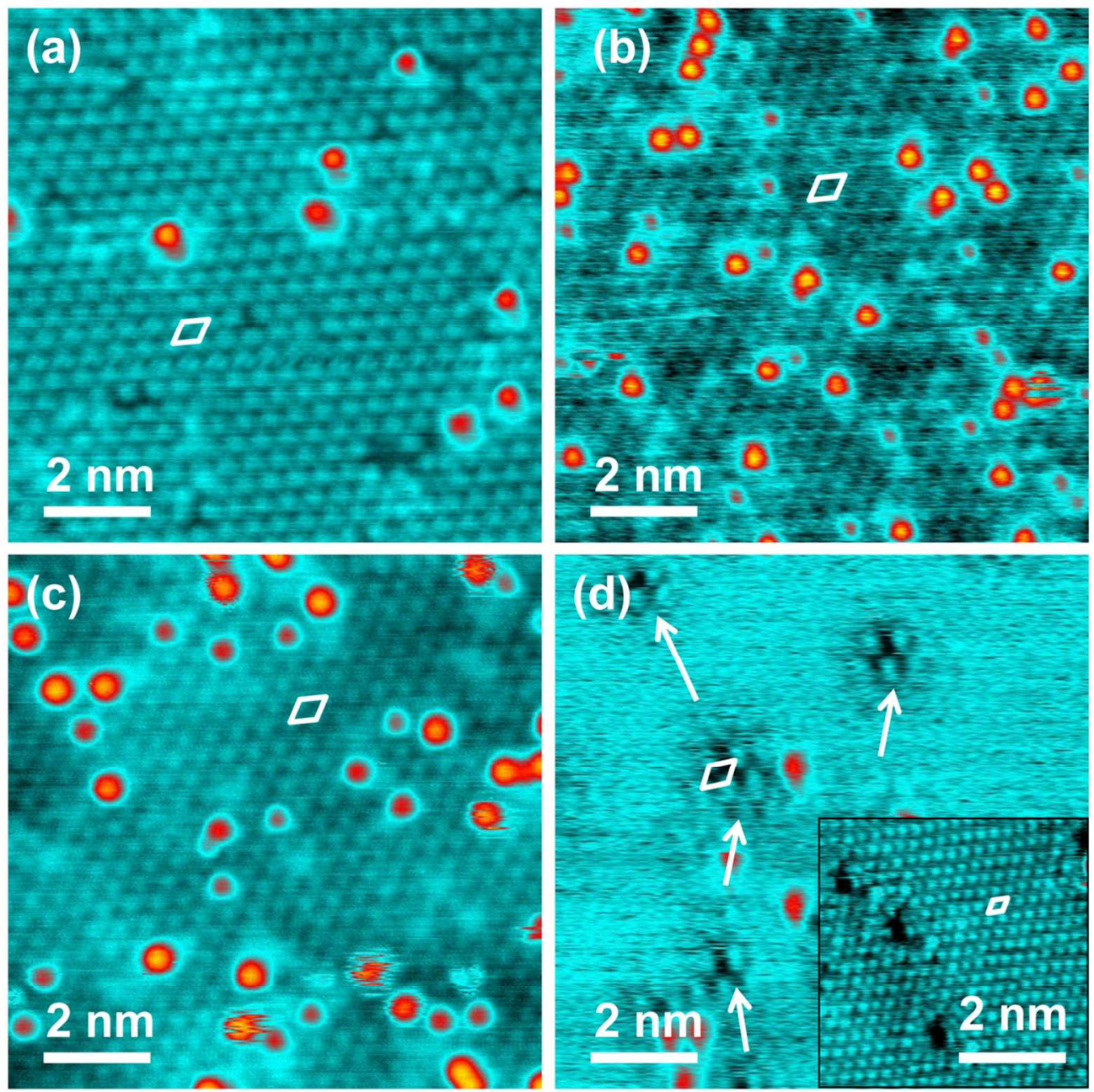

Figure 1. STM images of $\mathrm{Ni}-\mathrm{O}(2 \times 2)$ structures formed on $\mathrm{Ni}(111)$ after (a) exposing to $100 \mathrm{~L} \mathrm{CO}_{2}$ at room temperature; (b) after exposing to $100 \mathrm{~L} \mathrm{O}_{2}$ at RT followed by annealing at $773 \mathrm{~K}$; (c) after exposing to 0.4 mbar $\mathrm{CO}_{2}$ for 1 hour at $700 \mathrm{~K}$, transferred in air, and cleaned by sputtering and annealing; and (d) after further annealing the sample corresponds to panel (c) at $973 \mathrm{~K}$, leaving residual Chem-O islands dispersed on the flat surface [insert illustrates the same surface showing the $\mathrm{Ni}$ (111) lattice]. The unit cells were marked by diamonds, and measured as (a) $0.51 \pm 0.03 \mathrm{~nm}$, (b) $0.49 \pm 0.04 \mathrm{~nm}$, (c) $0.48 \pm 0.03 \mathrm{~nm}$, (d) $0.49 \pm 0.04 \mathrm{~nm}$ for the residual islands, and $0.25 \pm 0.02 \mathrm{~nm}$ for the insert. The bias voltages and tunneling currents were (a) $0.2 \mathrm{~V}, 0.1 \mathrm{nA}$; (b) $0.05 \mathrm{~V}, 0.5 \mathrm{nA}$; (c) $0.2 \mathrm{~V}, 0.1 \mathrm{nA}$; (d) $0.1 \mathrm{~V}, 0.2 \mathrm{nA}$, and the insert $0.1 \mathrm{~V}, 10 \mathrm{nA}$. $119 \times 119 \mathrm{~mm}(300 \times 300 \mathrm{DPI})$ 

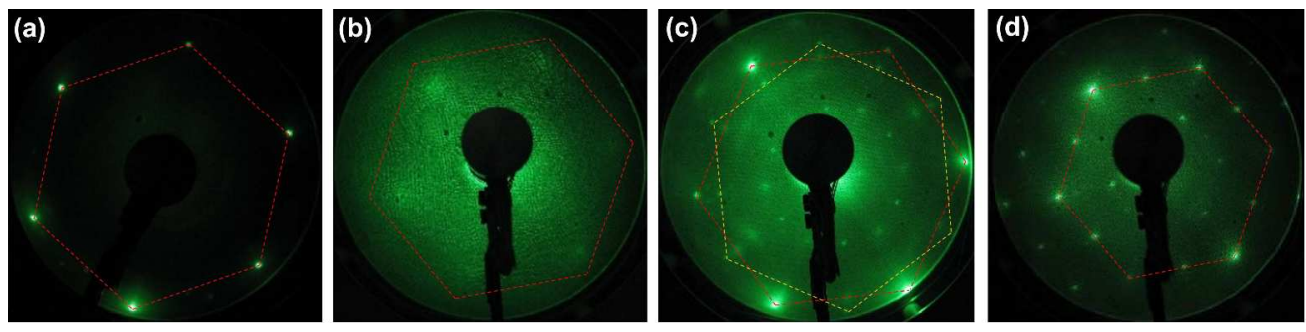

Figure 2. LEED patterns of (a) clean $\mathrm{Ni}(111)$, beam energy $70 \mathrm{eV}$; (b) after exposure to $0.4 \mathrm{mbar} \mathrm{CO}_{2}$ at $600 \mathrm{~K}$ for $30 \mathrm{~min}$, beam energy $70 \mathrm{eV}$, showing a shrinkage of the diffraction lattice consistent with epitaxial $\mathrm{NiO}$ (111) on $\mathrm{Ni}(111)$; and (c, d) the condition of (b) after UHV annealing, using 70 eV and 110 eV beams, showing the transition from $\mathrm{NiO}(111)$ to the $\mathrm{p}(2 \times 2)$ Chem-O structure. The hexagons in red dashed lines denote the unit diffraction lattice of clean $\mathrm{Ni}(111)$, and that in yellow dashed lines denotes a rotated pattern.

$617 \times 149 \mathrm{~mm}(300 \times 300 \mathrm{DPI})$ 

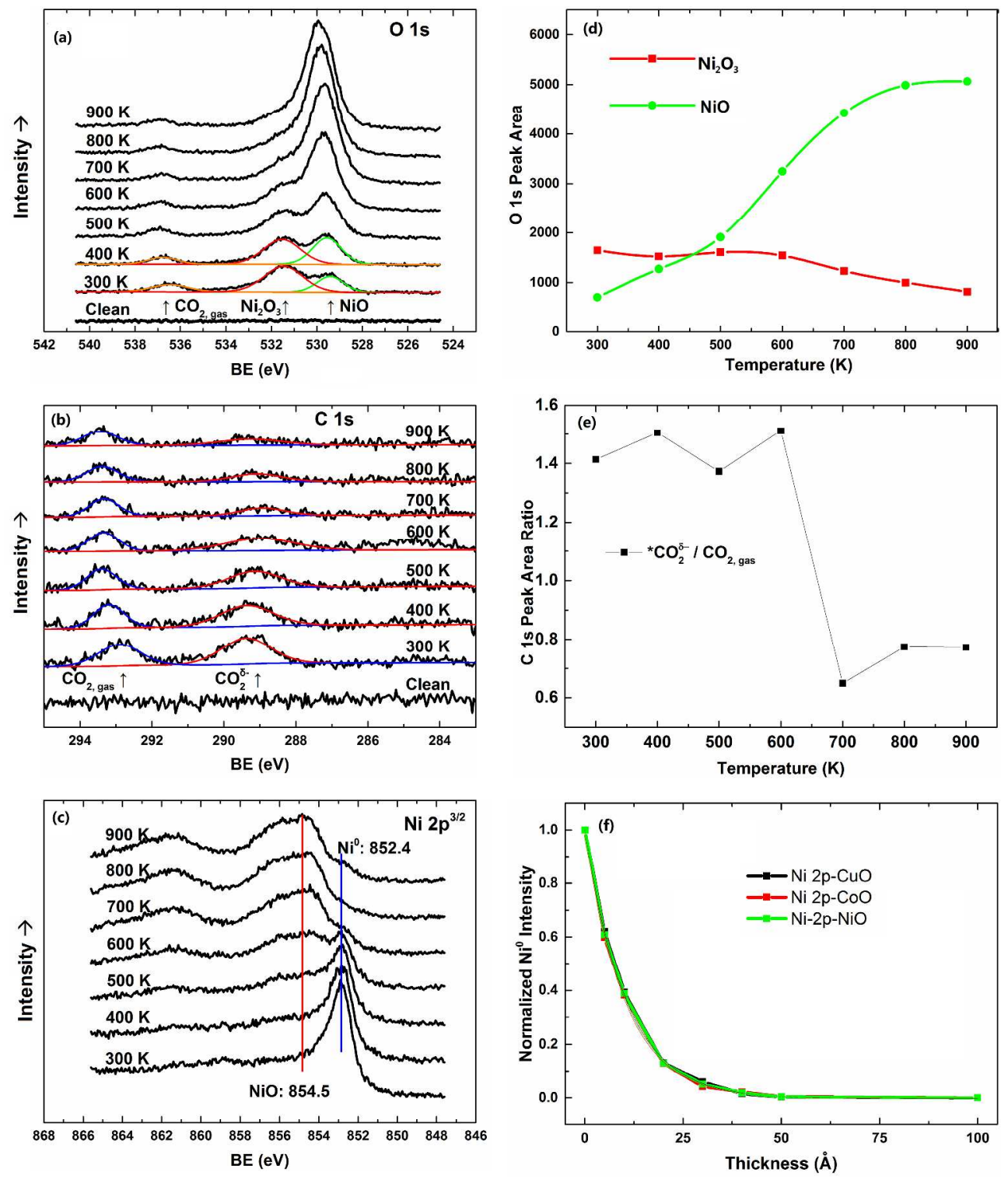

Figure 3. Temperature-programmed NAP-XPS under 0.4 mbar $\mathrm{CO}_{2}$ from $300 \mathrm{~K}$ to $900 \mathrm{~K}$. (a-c) $\mathrm{O} 1 \mathrm{~s}, \mathrm{C} 1 \mathrm{~s}$ and $\mathrm{Ni} 2 \mathrm{p}_{3 / 2}$ peaks. (d) Fitted $\mathrm{O} 1 \mathrm{~s}$ areas by $\mathrm{NiO}$ (green) and $\mathrm{Ni}_{2} \mathrm{O}_{3}$ (red). (e) $\mathrm{C} 1 \mathrm{~s}$ area ratio of $* \mathrm{CO}_{2}{ }^{\delta-}$ $/ \mathrm{CO}_{2, g a s}$. (f) SESSA 2.0 simulated $\mathrm{Ni}^{\circ} 2 \mathrm{p}$ intensity (normalized) from nickel substrates covered by $\mathrm{CuO}, \mathrm{CoO}$, and $\mathrm{NiO}$ with varying thicknesses.

$1481 \times 1710 \mathrm{~mm}(96 \times 96 \mathrm{DPI})$ 

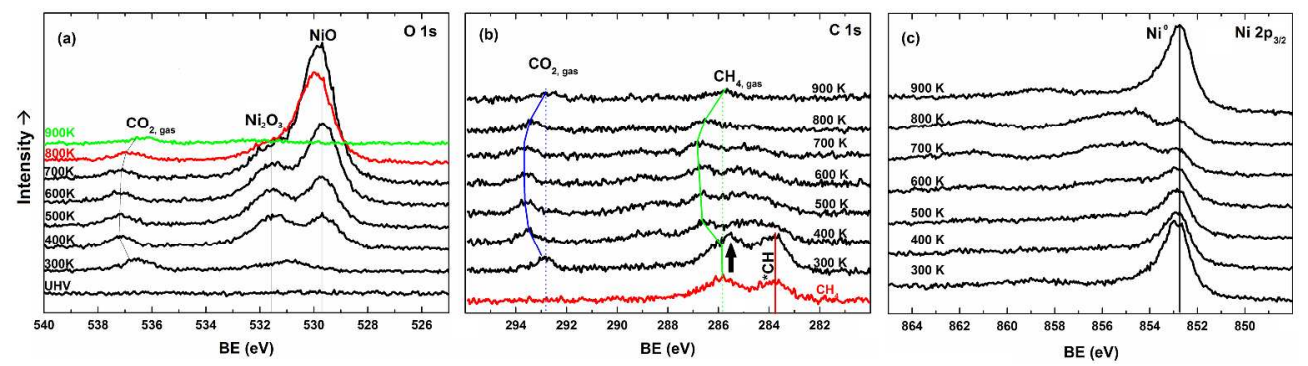

Figure 4. Temperature-programmed XP spectra of (a) $\mathrm{O} 1 \mathrm{~s}$, (b) $\mathrm{C}$ 1s and (c) $\mathrm{Ni} 2 \mathrm{p}_{3 / 2}$ under 0.4 mbar $\mathrm{CH}_{4}$ and 0.4 mbar $\mathrm{CO}_{2}$.

$2036 \times 556 \mathrm{~mm}$ (96 x 96 DPI) 

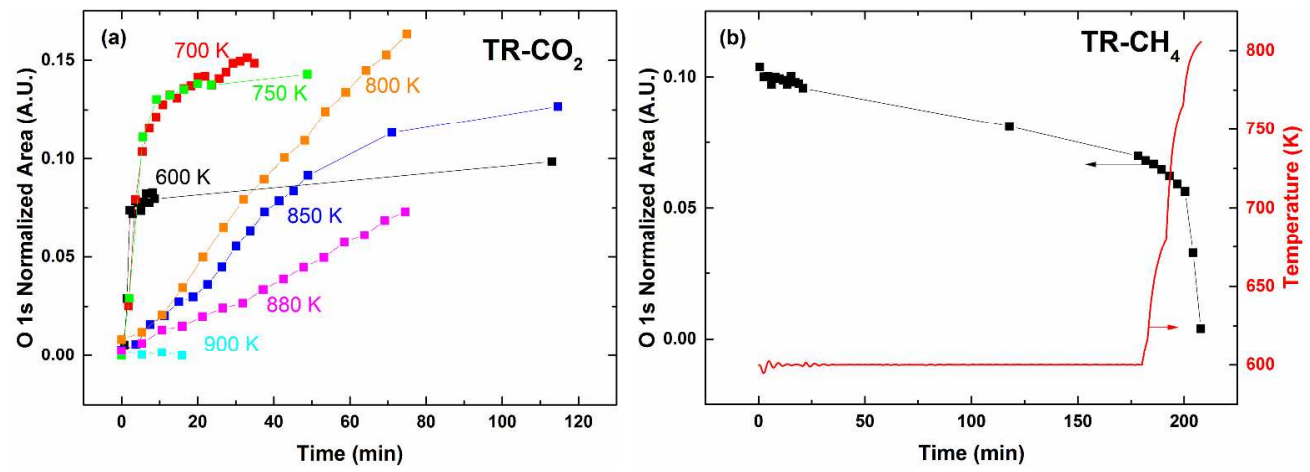

Figure 5. Time-resolved NAP-XPS showing the $O$ 1s peak evolution. (a) Accumulation of oxygen under 0.4 mbar $\mathrm{CO}_{2}$ at varying temperatures; (b) the reduction of the $\mathrm{Ni}-\mathrm{O}$ phase under $0.3 \mathrm{mbar} \mathrm{CH}_{4}$, prepared from the oxidation in (a) at $600 \mathrm{~K}$. $1494 \times 522 \mathrm{~mm}(96 \times 96 \mathrm{DPI})$ 

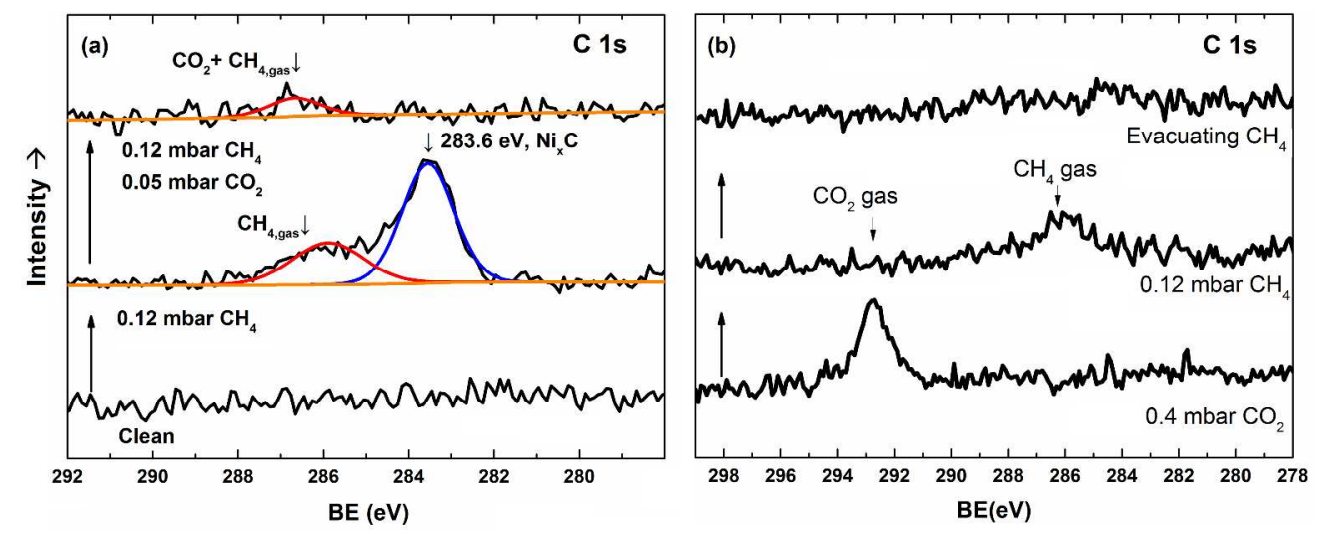

Figure 6. Titration experiments at $700 \mathrm{~K}$ with varying gas dosing sequences. In (a), the Ni (111) was first exposed to 0.12 mbar $\mathrm{CH}_{4}$ at $700 \mathrm{~K}$ and $\mathrm{Ni}_{\mathrm{x}} \mathrm{C}$ clusters were formed; after adding another $0.05 \mathrm{mbar}^{\mathrm{CO}}{ }_{2}$, the $\mathrm{NixC}$ phase disappeared. In (b), the $\mathrm{Ni}(111)$ was first exposed to 0.4 mbar $\mathrm{CO}_{2}$ at $700 \mathrm{~K}$ to form a $\mathrm{NiO}$ surface; after evacuating the $\mathrm{CO}_{2}$ and adding $0.12 \mathrm{mbar}^{\mathrm{CH}} \mathrm{H}_{4}$, no carbon deposition was observed on the oxidized surface except for the gas phase $\mathrm{CH}_{4}$ peak, which disappeared after evacuating $\mathrm{CH}_{4}$. 


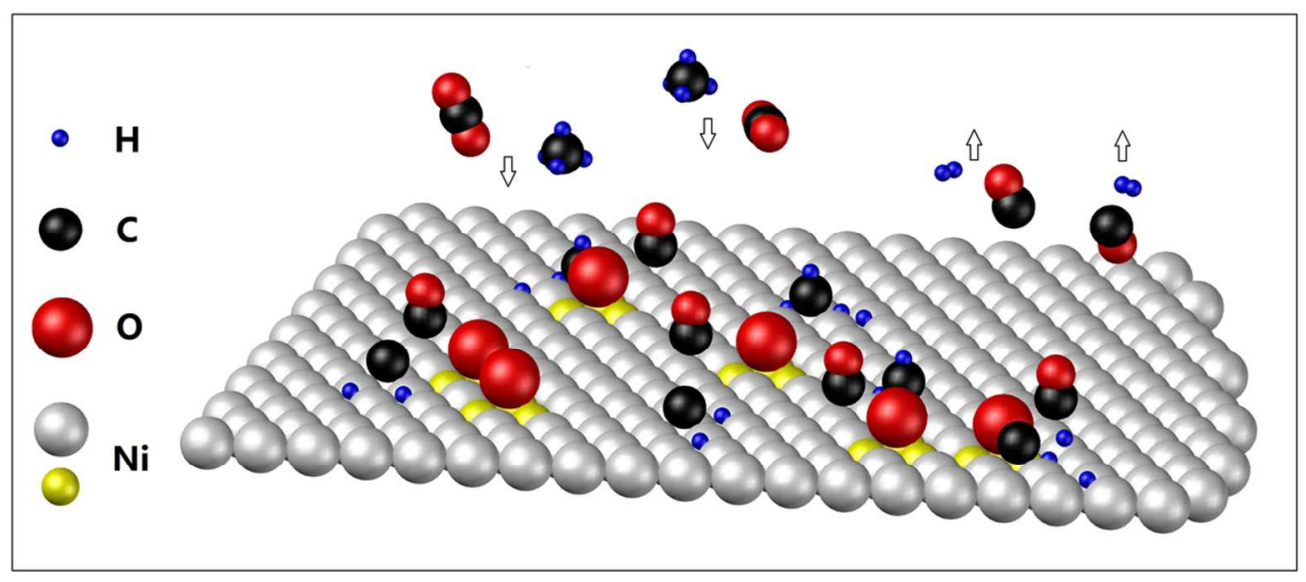

Table of Contents Graphic $98 \times 43 \mathrm{~mm}(300 \times 300 \mathrm{DPI})$ 